IZA DP No. 10073

How Do Pre-School and/or School-Age Children Affect Parents' Likelihood of Migration and Off-Farm Work in Rural China's Minority Regions?

Sai Ding

Xiao-yuan Dong

Margaret Maurer-Fazio

July 2016 


\title{
How Do Pre-School and/or School-Age Children Affect Parents' Likelihood of Migration and Off-Farm Work in Rural China's Minority Regions?
}

\author{
Sai Ding \\ Chinese Academy of Social Sciences \\ Xiao-yuan Dong \\ University of Winnipeg \\ Margaret Maurer-Fazio \\ Bates College and IZA
}

Discussion Paper No. 10073

July 2016

IZA

P.O. Box 7240

53072 Bonn

Germany

Phone: +49-228-3894-0

Fax: +49-228-3894-180

E-mail: iza@iza.org

Any opinions expressed here are those of the author(s) and not those of IZA. Research published in this series may include views on policy, but the institute itself takes no institutional policy positions. The IZA research network is committed to the IZA Guiding Principles of Research Integrity.

The Institute for the Study of Labor (IZA) in Bonn is a local and virtual international research center and a place of communication between science, politics and business. IZA is an independent nonprofit organization supported by Deutsche Post Foundation. The center is associated with the University of Bonn and offers a stimulating research environment through its international network, workshops and conferences, data service, project support, research visits and doctoral program. IZA engages in (i) original and internationally competitive research in all fields of labor economics, (ii) development of policy concepts, and (iii) dissemination of research results and concepts to the interested public.

IZA Discussion Papers often represent preliminary work and are circulated to encourage discussion. Citation of such a paper should account for its provisional character. A revised version may be available directly from the author. 


\section{ABSTRACT \\ How Do Pre-School and/or School-Age Children Affect Parents' Likelihood of Migration and Off-Farm Work in Rural China's Minority Regions?}

In this paper we explore the intersectionality of religious and ethnic norms and gender relations across the domestic and public spheres of work in post-reform rural, minorityconcentrated China. We focus on the role that children play in their parents' off-farm work decisions for three aggregated ethnic groups (majority Han, Muslim minorities, and nonMuslim minorities). We control for households' composition and economic characteristics and individuals' human capital and as well as local economic conditions. Children generally decrease women's willingness to work away from/outside the home and increase men's willingness to do so. When we focus specifically on the effects of pre-school children, our results suggest it is more socially acceptable for non-Muslim than Muslim women to work away from home. When we turn our attention to school-age children, the gender of the child becomes as important to the analysis as the gender of the parent. With regard to household composition, we find that in Muslim households the presence of extra adult men (of any age between 15 and 70) in the household reduces the likelihood that women engage in off-farm work. The presence in the household of a woman of grandmotherly age (between 46 and 70) supports Muslim minority women's ability to migrate for work. For non-Muslim households, grandfathers and grandmothers alike, facilitate the ability of parents (male and female) to migrate for work.

JEL Classification: J14, J15, J16, J26, D13, O53

Keywords: off-farm work, ethnicity, household composition, children, migration, China

Corresponding author:

Margaret Maurer-Fazio

Bates College

276 Pettengill Hall

4 Andrews Road

Lewiston, Maine 04240

USA

E-mail: mmaurer@bates.edu 


\section{How Do Pre-School and/or School-Age Children Affect Parents' Likelihood of Migration and Off-Farm Work in Rural China's Minority Regions?}

by

\section{Sai Ding, Xiao-yuan Dong, and Margaret Maurer-Fazio}

\section{Introduction}

Over the past three decades, China experienced fundamental economic transformations that have both moved laborers from agricultural to non-agricultural activities and rapidly increased rural-to-urban migration. The rapid expansion of off-farm employment fueled sharp rises in the labor productivity and real incomes of China's rural population. It lifted hundreds of millions of rural residents out of poverty. China's rural women are among the beneficiaries of these changes: the rise in rural income and the growth of wage employment in the off-farm sector provide women with a pathway for economic empowerment. However, women's ability to participate in these new income-generating activities is limited by a variety of constraints arising from gender norms and beliefs, women's limited control over resources, and labor market discrimination (Naila Kabeer 2008). Women's socially assigned responsibilities for domestic work and provision of care represent major impediments to women's participation in off-farm employment given that it is much more difficult for women to combine income-earning activities with care-giving responsibilities when those activities take place in non-agricultural rather than agricultural settings. China's rural women are less likely to be involved in local offfarm work than men (Qiao, Rozelle, Zhang, Yao, and Zhang 2015, Chang, MacPhail and Dong 2011;,Knight and Song 2003).

Furthermore, Chinese women's migration options are more limited than men's. Until recent years, female migrants were typically young and unmarried, while male migrants embodied a wider range of ages and marital statuses (Lee and Meng, 2010, Zhang, de Brauw, and Rozzelle 2004; Denise Hare 1999;). The massive migration of labor from rural to urban areas has left many middle-aged, married women to run the farms and to provide care for children, elderly parents, and those in poor health (Connelly and Maurer- 
Fazio, 2016; Kong and Meng, 2010). Agricultural production has increasingly become the work of women and the elderly (Connelly and Maurer-Fazio 2015; Qiao, Rozelle, Zhang, Yao, and Zhang 2015; Chang, Dong, and MacPhail 2011; Mu and Van de Walle 2011)

While a substantial amount of research has focused on gendered patterns of off-farm employment among the Han majority, relatively little is known about how the gendered patterns of off-farm employment vary across ethnic groups or about how ethnic minority women have fared in terms of access to off-farm employment relative to their male counterparts. According to China's 2010 Census of the Population, China is home to an ethnic minority population of approximately 112 million, one of the world's largest ethnic minority populations. The term ethnic minority is used here to refer to the 55 national minorities that, along with the Han majority, make up the 56 ethnic groups officially recognized by the Chinese central government. ${ }^{1}$ Considered from a different perspective, the 55 recognized ethnic minority groups constitute only 8.4 percent of the national population. The government classifies 10 of these ethnic minority groups, with a combined population exceeding 23 million, as Muslim. Of these, the Hui and Uyghurs are numerically the most important with populations, of 10.6 million and 10.1 million, respectively, according to the 2010 census.

This paper examines the impact of childcare responsibilities on women's and men's choices $^{2}$ regarding whether to participate in off-farm work ${ }^{3}$ in rural China's minority regions. The research question that guides our analysis is the following: How does

${ }^{1}$ In many other jurisdictions around the world, individuals self identify as being a member of an ethnic minority group. In contrast, in China, ethnic (nationality) minority status is assigned at birth, recorded on official identity documents, and in almost all cases fixed throughout one's life (Maurer-Fazio and Hasmath 2015).

2 In the rest of the paper we refer to these choices interchangeably as "employment type choice" and "occupational choice."

3 We generally include both work carried out locally and work in distant locations that requires rural residents' out-migration in the term "off-farm work." We separately consider these two types of off-farm work in the analysis that follows. 
household composition, in general, and the presence of pre-school and/or school-age children, in particular, affect the likelihood of women's and men's off-farm work in these regions? We explore this question in its larger context, which takes into account: individuals' human capital and productive attributes; households' composition and economic characteristics; local economic conditions (at both the village and the county levels); and cultural/religious/ethnic norms. Our research is comparative in nature--we analyze whether this complex set of factors differentially affects members of the Han and ethnic minority groups. We investigate whether observed Muslim/non-Muslim (both Han and minority) differences in the proclivity to engage in local off-farm employment and to migrate for work are best attributed to artifacts of local economic conditions, differences in individual productive attributes, household composition, or differences in cultural and religious norms. Comparing the role that children play in parents' employment-type decisions between Muslim and non-Muslim minority and Han majority households provides a window for observing the intersectionality of religious and cultural norms and gender relations across the domestic sphere of the household and the public sphere of work in the context of post-reform rural China. ${ }^{4}$

\section{Background}

Religion, family, and work are important sites for the formation, negotiation, and change of gender relations. How gender might intersect with religion depends upon its temporal and social contexts. As Niels Spierings (2014) notes, studies that focus on the role of patriarchy in predominately Muslim countries make use of a notion of "classical patriarchy" based on patrilineality and the idea of the male breadwinner/female homemaker dichotomy. He argues that this notion of patriarchy implies differences in female employment according to women's household composition. Spierings exploits

${ }^{4}$ As Ebru Kongar, Jennifer C. Olmsted, and Elora Shehabuddin (2014) point out, there are very complex relationships between the economic, political, cultural, and religious spheres that affect people's lives and that it is critical to take intersectionality, historical context, and structural constraints into account when considering the multiplicity of women and men's experiences by religion and ethnicity (amongst other factors). 
variation in the importance of these two aspects of patriarchy across 28 Muslim-majority countries to form testable hypotheses about differences in women's employment across these countries. In the work that follows, we too, explore differences in the effects of patriarchal norms by investigating how these norms vary across ethnic groups in rural China and in turn affect both women's and men's proclivities to work locally off-farm and to migrate across county and provincial borders in search of employment opportunities.

In traditional/imperial China, both Muslim and non-Muslim women were conceptualized as subordinate to men. A female-inside/male-outside patriarchal dichotomy characterized the gendered division of labor within the household in both traditional Confucian and Islamic family cultures. Appropriate roles for women in both cultures were envisioned as those that supported the family and took place inside the household. Appropriate roles for men were envisioned as those that provided for the family through activities outside of the household. Traditional Confucian doctrine espouses an extremely hierarchical view of society in which the position of women is ascribed as lowly and weak and meant to serve others (Elisabeth Croll 1995). The traditional Muslim family structure, like the traditional Chinese family, is typically portrayed as based on an authoritarian, patriarchal hierarchy. Xiaowei Zang (2008) notes that its views of women's roles also regard women as the repositories of family honor and that preservation of family honor entails restrictions on women's behavior with regard to dress, mobility, and contact with men outside of their own families. Motherhood takes on an additional special role as a key safeguard of Islamic culture (Zang 2008).

After the founding of the People's Republic of China, the Communist Party fought against beliefs that disparaged women and lowered their societal status and instead promoted and promulgated a rhetoric and ideology of gender equality. In the Maoist/socialist era (1949-1976), women's labor force participation increased dramatically and was viewed as a form of liberation. Women were lauded as holding up "half of heaven," a traditionally male realm (Croll 1995). The discourse of the period suggests that Chinese women's participation in paid labor improved their status markedly. 
The dual-earner household became the new norm of the Chinese family. Women, however, continued to bear the lion's share of unpaid domestic and care work,

It appears, however, that the Chinese women's emancipation movement did not exert the same degree of influence on Muslims as it did on non-Muslims, especially in the rural sector. Although China's constitution stipulates than all women and men should have equal rights, economically, socially and politically, Chinese policy makers deemed particular gender issues in Muslim areas to be part of Muslim culture not subject to state intervention (Xiaowei Zang 2012). The marriage law of 1950 allowed both polygamy and traditional divorce law in Muslim regions (Barry Sautman 1998). Although, China’s current marriage law stipulates, in general, that the legal age of first marriage is age 22 for men and age 20 for women, it reduces these age limits to age 20 and age 18 for minority men and women, respectively. Autonomous minority regions also have the right to issue legislation allowing even further reductions in the marriage age for their poorer and more remote communities and Xinjiang has exercised this right (Sautman 1998).

China's birth control policies also differentiate ethnic minorities and Han Chinese and impose stricter limits on the Han. From the inception of the severe family planning policies of 1982 until the end of 2015, most Han Chinese urban couples were allowed to have only one child while rural Han couples were allowed to have a second child under certain conditions such as when the first child was female. For most ethnic minorities the birth control quota was set at two for urban couples and three for rural couples. At particular times under particular circumstances these less stringent ethnic limits were further relaxed for particular groups (Sautman 1998). No doubt, state policy is only one of the factors that influence women's fertility decisions. Over time, as women's education and employment opportunities improved, fertility rates for both Muslim and non-Muslim households declined. Nonetheless, the average fertility rate of Muslim families is higher than that of non-Muslim minority and Han families, as we show in section 5 below. 
In the reform and post-reform eras, the declining influence of socialist egalitarian ideology has led both to a resurgence of traditional Confucian culture and an increasing social, political, and religious impact of Islam. The concomitant rise of patriarchal values and norms represents a major setback to Chinese women's hard-won battles for greater gender equality. It has affected Muslim and non-Muslim women differently as Muslim women confront more socioeconomic constraints than non-Muslim women, which make it particularly difficult for Muslim women to break away from patriarchal gender relations. For example, Uighurs, a visible minority, may be more likely than members of most other ethnic minority groups to be subject to Han chauvinism and/or discrimination in the labor market. ${ }^{5}$ The Hui, who are ethnically very close to the Han, are distinguished from the Han mainly because of being Muslim (Mackerras 2005). Even though the Hui are similar to the Han in physical appearance and language, they may still find themselves discriminated against because of dietary customs, dress, ${ }^{6}$ or religious practices. In addition, ethnic minorities in rural areas, Muslim and non-Muslim alike, may find their employment options limited by the extent to which they lack an ability to communicate in Mandarin (Putonghua) or the local Han dialect. The higher fertility rate of Muslim families may further hinder Muslim women's ability to work outside the home. The intersection of these multiple socioeconomic disadvantages may make it difficult for Muslim women to move away/break away from the legacy of traditional gender role expectations.

\section{Literature Review}

In this brief review of the related literature, we first discuss studies of rural households that address the effects of children on parents' decisions about migrating for work and/or working off-farm. We then review a set of studies that add analyses of the influence of

\footnotetext{
${ }^{5}$ Maurer-Fazio's resume audit study of job applicants using Internet job boards in 6 large Chinese cities found that college-educated Uyghur women had to put in almost twice as many applications as their equally qualified Han counterparts just to obtain the same number of interview callbacks (Maurer-Fazio, 2012).

${ }^{6}$ In Hui areas, Hui women typically wear headscarves and Hui men white caps. Some family names also signal a strong likelihood of being Hui (Gustafsson and Ding, 2014).
} 
both patriarchal norms and ethnicity. We conclude this section with a set of related, testable hypotheses.

The studies that analyze the effects of children on their parents' off-farm work and migration decisions for rural households have yielded results that vary by the age of the children. Qiao et al. (2015) find that the presence of pre-school-age children in the household affects neither their parents' decisions to migrate or to work off-farm. Although Yaohui Zhao (1999) also finds that presence of preschool children has no effect on parents' migration decisions, she does find that it decrease parents' participation in local off-farm work. In contrast, Qiao et al. (2015) find that school-aged children (as opposed to preschool children) increase parents' likelihood of participation in local offfarm work while decreasing their probability of migration.

Several studies reveal that grandparents play an important role in parents' work and migration decisions. Feinian Chen, Guangya Liu, and Christine A. Mair (2011) demonstrate that grandparent-provided childcare has become increasingly common, in both urban and rural China, in the post reform period. They interpret grandparentprovided care as the outcome of families' decisions to alleviate mothers' burdens to enable them to pursue income-earning opportunities -- thereby maximizing the wellbeing of the larger family. The role of grandparents in childcare is confirmed in the findings of Chang, Dong and MacPhail (2011), which reveal that preschool children increase the number of hours spent on housework and care work by both elderly men and elderly women, more so for women than men. Connelly, Roberts and Zheng (2012) claim that with grandparents' participation in childcare, the presence of children is no longer a binding constraint on the migration decisions of rural mothers, although it affects the timing of their migrations. They report that many migrant mothers return to their rural homes around the time that their children begin formal schooling. The grandmothers providing care for preschool-age children are typically less educated than their daughters and are not considered a good maternal substitute for assisting children with school homework. 
We turn next to a subset of the literature that compares reform-era labor market outcomes of China's ethnic minorities and Han majority. Early papers by Gustafsson and Li (2003) and Hannum and Xie (1998) both suggest that minorities did not fare as well as the Han as China transformed its economy from socialist to market orientation-the gap between minorities and the Han widened in terms of both rural income and occupational attainment. Gustafsson and Li question whether the fundamental cause of the growth in these gaps is location rather than ethnic discrimination and come down on the side of location. Hannum and Xie argue otherwise and claim that important ethnic differences in labor market outcomes remain even after carefully taking location into account.

Focusing on the urban sector and examining the gendered patterns of labor force participation revealed in the data of China's population censuses of 1990 and 2000, Maurer-Fazio, Hughes, and Zhang (2007) find that minority women experienced larger decreases in labor force participation and had lower rates of participation than either minority men or Han men and women, and the decline was especially pronounced for Hui women. They argue that the decline in Hui women's labor force participation was indicative of a robust cultural or religious difference that surfaced with the relaxation of state control over individuals' lives. Maurer-Fazio, Hughes, and Zhang (2010) find that the market and social treatment of Han attributes tend to ease women's entry into the labor force, while minority women appear to be rich in levels of those attributes that discourage market work at the margin. Xiaowei Zang (2012) finds, based on 2005 survey data from Xinjiang's capital, Urumchi, both sizable earnings differentials between Han Chinese and Uyghurs and striking gender differences in the earnings differentials between the two ethnic groups. Zang attributes men's earning differentials primarily to socioeconomic differences between the two groups and women's earnings differentials to differences not only in socioeconomic status but also to differences in family responsibilities. Zang argues that while both Han and Uyghur women in Urumchi suffer labor market penalties attributable to housework and motherhood, the negative effect is greater for Uyghur women due to Muslim family norms that strengthen women's attachment to traditional gendered division of household labor. 
Only a handful of studies have specifically investigated how ethnic identity affects rural individuals' participation in off-farm employment and labor migration. They reveal that ethnic minority status generally tends to reduce the probability of participating in the migration process although one or two minorities are observed to have higher probabilities of migration than the majority Han population (Gustafsson and Yang 2015; Howell, Gustasson and Ding 2015; Howell and Fan 2011). Connelly and Maurer-Fazio (2015), focusing on China's rural elders, find that beyond education, the strongest predictors of labor force participation are age, disability, widowhood, and ethnic minority status. Social prejudice, labor market discrimination, lack of skills in, or facility with, Mandarin Chinese (Putonghua) language or local Han dialects, and lack of access to social networks at potential destinations are among the main obstacles to ethnic minority workers' entry into the off-farm and urban labor markets (Chen, Lu, and Xu 2014; Maurer-Fazio 2012; Gao and Smythe 2011). Gaining a clear understanding of how gender intersects with ethnicity-based constraints is of critical importance for the design of inclusive employment and anti-poverty strategies and policies.

Spierings (2014) unpacks the notion of patriarchy to build a theoretical framework that allows for careful analysis of differences in women’s employment in Muslim-majority countries. He expands the notion of household composition to include more than the standard factors of marital status and the presence/number of children. He reports that the presence of other adult women in the household is one of the strongest positive influences on women's employment—presumably these other women help to alleviate the care burden. With regard to children, Spierings reports that women's employment decreases with the number of children (under age 13) but that the strength of this effect is determined by the strength of local patriarchal norms. Spierings also finds that the higher the number of male breadwinners within a household, the lower the probability of women's employment. In the empirical work that follows, we too, explore the effects of similarly nuanced notions of household composition on women's and men's employment.

In the remainder of the paper we examine, after carefully controlling for household composition and local economic conditions, the impact of having preschool or/and 
school-aged children on the off-farm work decisions of women and men in China's minority regions and compare the differences in these impacts between Muslim and nonMuslim (Han and minority) households. Our analysis seeks to test the following hypotheses:

Hypothesis 1: Due to traditional gender role expectations, children decrease women's willingness and ability to work outside the home, whereas they increase men's desire to seek employment in the off-farm sector, which generates higher earnings. We expect that the gap in men's and women's off-farm employment to be greater for Muslims than nonMuslims.

Hypothesis 2: Women's likelihood of off-farm employment will decrease with the presence in the household of adult men (potential breadwinners in addition to their spouses). We expect that this effect is stronger for Muslim women than for non-Muslim women.

Hypothesis 3: Women's likelihood of off-farm employment will increase with the presence of (other) non-elderly adult female co-residents as these other women will presumably alleviate/mitigate the burden of care for other household members.

\section{Empirical Methodology}

In the analysis that follows, we focus on married women and men between the ages of 18 and 45. We divide their economic activities into three mutually exclusive categories: farm work, local off-farm work, and nonlocal off-farm work, and define a categorical variable which is equal to zero if the individual participates in farm work only; equal to one if the individual participates in off-farm work within his/her county of residence, and equal to two if the individual migrates out of his/her home county to participate in off-farm work. We assume that individuals compare the benefits and costs of these alternative activities to make choices that maximize their utility. We also assume that these costs and benefits are in turn affected by/determined by the characteristics of the individual and the composition of his/her household and the economic conditions at the village, county, and 
provincial levels. We thus estimate the determination of women's and men's choices using a multinomial logit model:

$\ln \left(\frac{P_{j}}{P_{0}}\right)=\beta_{0 j}+\beta_{1 j}{ }^{\prime} C+\beta_{2 j}{ }^{\prime} H+\beta_{3 j}{ }^{\prime} X+\beta^{\prime}{ }_{4 j} Z$

In this model, $\mathrm{P}_{0}$ is the probability of participating in farm work (the reference category) and $P_{j}$ stands for the probability of the $j$-th type of occupation with $j=1$ for local off-farm work and $\mathrm{j}=2$ for migration/nonlocal off-farm work. The Greek letters represent unknown parameters. $\mathrm{C}$ is a vector of binary variables representing the presence of preschool and/or school-aged boys and girls. H represents a vector of variables of household characteristics that includes the gender and age composition of other adults in the household and household asset income. X represents a vector of variables for individual characteristics that includes education, age intervals, and a binary indicator of being able to communicate in Mandarin (Putonghua) or the local Han dialect. And, $\mathrm{Z}$ is a vector of variables for regional/locational characteristics that includes the distance from the village to the nearest bus stop, village per capita farmland and village per capita income, binary indicators for the presence of a kindergarten and/or a primary school in the village, the proportion of migrant workers in the village labor force, county-level per capita GDP, the share of primary industry in county GDP, and provincial fixed-effects. We estimate Equation (1) separately for Muslim minority women, Muslim minority men, non-Muslim minority women, non-Muslim minority men, Han women and Han men.

One major concern about this regression model is that the variables that represent whether an individual has a pre-school child may be endogenous. Unobserved characteristics may affect both occupational choice and fertility decisions such that these decisions might be made jointly. Unfortunately, we are unable to econometrically address this concern about potential endogeneity due to the lack of valid instrumental variables (IVs). However, as argued by Connelly, DeGraff, Levison and McCall (2006), such a lack of viable instrumental variables should not prevent us from investigating the issues of policy interest given that the endogeneity of fertility is a matter of degree. Speaking in terms of its biology, fertility, which cannot be planned exactly, always contains exogenous elements. In developing countries, there are many economic and social factors 
that increase exogenous variations in fertility, thereby weakening its simultaneous association with employment decisions. Arguably, religious beliefs may limit Muslim families' willingness to use birth control devices, while China's birth-control policies impose particular constraints on Han families' fertility decisions. Based on their findings in urban Brazil, Connelly et al. (2006, p.26) argued that "at least in the case of recent fertility in a developing country context, there are good reasons to hypothesize that the endogeneity of recent fertility with respect to women's current employment should be small."7

\section{Data}

Our analysis employs data from the China Ethnicity Household Survey (CHES) conducted in 2012. The survey group collected information on 14,576 urban and rural households in seven 7 provinces and provincial-level autonomous regions: Inner Mongolia, Hunan, Ningxia, Guangxi, Guizhou, Qinghai, and Xinjiang. Within each sampled region, the sample frame was based on the urban and rural household registries of the Bureaus of Statistics and employed stratified random sampling methods. This paper is based on the rural sample, which in total includes over 30,000 individuals of more than 7,000 households of hundreds of villages located across 81 counties. The sampled locations tend to be poor, remote, and characterized by low incomes and land shortages. Our analytical sample, which is limited to rural married individuals between the ages of 18 and 45 consists of 897 Muslim women, 916 Muslim men, 1,798 nonMuslim minority women, 1,777 non-Muslim minority men, 1,477 Han women, and 1,514 Han men. The data set's information on employment/occupational choice, the focus of this paper, refers to respondents' type of employment in 2011.

\footnotetext{
7 The variables that represent the presence of adults older than 45 may be also considered endogenous for reasons similar to those for the presence of preschool children. Due to data limitations, we are unable to test this possibility. In our sample, the endogeneity of parents' co-residence with their adult children is also likely to be small as the co-residence choices of parents in less developed rural areas are limited. Patrilocal co-residence norms limit the presence of selection bias to those who have more than one son. The lack of alternatives to familial caregiving for the frail elderly creates exogenous variations in the variables that represent the presence of older parents in the household.
} 
In Table 1, we present summary statistics on incomes, poverty rates, and employment patterns by ethnicity for the women and men included in our sample. There, we see that both Muslim and non-Muslim minority households have markedly lower per capita incomes and markedly higher rates of poverty (19\% and 21\% versus 9\%) than Han households. Non-Muslim minority households are somewhat poorer than Muslim minority households. We also observe that in each of our three ethnic groups women are more likely than men to participate in farm work and less likely to participate in off-farm work (whether local or involving out-migration). The gender gap in rates of off-farm employment (adding together rates of both local and distant work) is greatest for Muslim minorities, and least for non-Muslim minorities, with the Han in the middle. Specifically, $79 \%$ of Muslim minority men participated in off-farm work while only $23 \%$ of Muslim minority women did so. For non-Muslim minorities the respective figures are $77 \%$ for men and $41 \%$ for women, while the respective figures for the Han are $71 \%$ for men and $30 \%$ for women. The gender gap in out-migration for off-farm work is also noticeably larger for Muslim minorities than either the non-Muslim minority or Han groups: only $7.9 \%$ of Muslim minority women, $17.8 \%$ of non-Muslim minority women and $11.2 \%$ of Han women migrated away from their home counties for work, while in contrast, the figures for men were $34.6 \%$ for Muslim minorities, 30\% for non-Muslim minorities and $23 \%$ for the Han.

(Insert Table 1 here.)

In Table 2, we present information on the gender and age composition of all members of the households of the individuals included in our analysis. Recalling that the subjects of our analysis are married individuals between the ages of 18 and 45, we note the Muslim minority households have a mean of 1.5 children that are between birth and 14 years of age, while the households of both non-Muslim minorities and Han have means of 1.1 children in this age range. We also note that the Muslim households of our sample are somewhat larger than those of the non-Muslim minorities and the Han with 5.4, 5.1 and 4.7 household members on average, respectively. (Insert Table 2 here.) 
In Table 3, we present descriptive statistics about the human capital of the individuals in our sample. We focus here on education, language capability, and the networks used to find employment. Women of each our ethnic groupings, lag behind men in educational attainment and language capabilities in Mandarin or the local Han dialect. That said, the gender gaps in these factors are similar for Muslim and non-Muslim households. When searching for off-farm employment, whether local or distant, our survey respondents report relying quite heavily on private networks -- those provided by either family and relatives or by friends and acquaintances. In this regard, Muslim men and non-Muslims (women and men) rely more heavily on friends and acquaintances than family and relatives. Muslim minority women, however, rely most heavily on family and relatives when seeking off-farm employment, which is consistent with the notion that their circle of social contacts outside the household is more limited than that of non-Muslim minority and Han women's.

(Insert Table 3 here.)

\section{Results}

In this section, we first discuss the factors that affect the occupational/employment-type choices of rural minority Muslim women and men. We follow this discussion with similarly structured ones for rural minority non-Muslim women and men and rural Han women and men. \{We present multinomial logit estimates of the marginal effects of factors affecting occupational choice for Muslim minority women and men in Table 4, for non-Muslim minority women and men in Table 5, and Han women and men in Table 6.

\section{6.a Rural Minority Muslim Women and Men}

In Hypothesis 1, we stated that we expected children to decrease women's willingness and ability to work outside the home and that we expected children to increase men's willingness to work off-farm. The estimates presented in Table 4 provide evidence that supports both parts of this hypothesis. In our empirical work we have explored the effects of children in a relatively nuanced way by disaggregating the category of "children” into four distinct groups — separating pre-school and school-age girls and boys. We find 
specifically, that having a preschool child of either sex increases Muslim women's probability of working on the farm by 12 percentage points and decreases their probability of migrating/working outside the county by 7 percentage points. In contrast, having a preschool girl or boy decreases Muslim men's probability of participating in farm work by 8 and 9 percentage points, respectively, and increases their probability of participating in local off-farm work by 12 and 13 percentage points. Preschool children do not appear to significantly affect either Muslim men's probability of out migration or Muslim women's participation in local off-farm work.

(Insert Table 4 here.)

Having a school-age daughter affects Muslim women's probability of participating in farm work and of out migration similarly to that of a preschool child, although the magnitudes of the effects are somewhat muted. School-age daughters increase their mothers' probability of working on the farm by 7 percentage points and decrease their probability of distant off-farm work by 5 percentage points. Surprisingly, having a school-age son seems to have no significant effect on Muslim women’s off-farm work decisions. The effects of school-age children on Muslim men's off-farm work decisions are also weaker than those of preschool children-- having a school-age boy has only a moderately significant negative effect on his father's participation in farm work and no significant effect on off-farm work. School-age girls do not appear to affect their father's farm/off-farm work decisions in a statistically significant manner.

We next turn to look at the effects of other gender and age aspects of household composition to gain additional insight into how gender role expectations affect women and men's off-farm work decisions. Just as Spierings (2014) reports that for the 28 Muslim-majority countries of his study, the higher the number of male breadwinners within a household, the lower the probability of women's employment, we too find that presence in the household of men anywhere between 15 and 70 years of age of increases Muslim women's probability of participating in farm work (effectively staying at home) and decreases their probability of participating in local off-farm work. Spierings finds that the presence of other adult women in the household has a very strong positive effect 
on women's employment. We too, find that the presence of other women, but only those between 46-70 years of age, increases women's probability of out migration by 6 percentage points. Presumably many of these mature women are grandparents providing childcare and alleviating the care burden of prime-age women.

For Muslim men, the presence of other men between the ages of 46 and 70 has a strong significant effect on their off-farm types of employment. The presence in the household of these additional mature, grandfather age, men decreases our subjects' probability of participation in local off-farm work by 12.6 percentage points and increases their probability of out migration by 13.4 percentage points. It has no impact on their probability of farming. Taken together, the above results, focused on the effects of household composition, suggest that the intergenerational division of labor in Muslim households is segregated along gender lines.

With respect to the effects of individuals' characteristics, we note that for both Muslim women and men, senior high school or post-secondary education lowers the probability of participating in farm work and raises the probability of participating in local off-farm work. However, education does not appear to be an important determinant of the migration decisions of either sex. While own age appears to have no effect on men's offfarm work decisions, it does have a significant effect on women. Compared with youngest cohort of women in our study, women aged between 25 and 34 are less likely to participate in farm work and are more likely to migrate for off-farm work, whereas women between 35 and 39 are less likely to participate in farm work and more likely to participate in off-farm work, but locally. We find no statistically significant effect for Muslim women and men of their ability to communicate in Mandarin on off-farm work decisions. $^{8}$

8 Although space constraints prevent us from discussing the effects of the particular village and county and provincial controls included in our regressions, their coefficients are included in Tables 4, 5, \& 6. 


\section{6.b Rural Non-Muslim Minority Women and Men}

Table 5 presents the multinomial logit estimates of the marginal effects of factors affecting the occupational choice for the non-Muslim minority women and men in our study. For the non-Muslim minorities just as for Muslim minorities, the presence of preschool-age children affects parents' off-farm work decisions differently by gender. It decreases women's probability of participating in off-farm work and increases men's. The effects, however, are somewhat smaller in size for non-Muslim than Muslim minorities. While Muslim women's choices about type of employment are affected by the presence of both preschool girls and preschool boys, for non-Muslim minority women only preschool girls have a significant effect. Furthermore, this effect of having a preschool girl on the probability of farming is smaller for non-Muslim minority women than Muslim women. It increases the probability that non-Muslim minority women participate in farm work by 6.1percentage points, which is 5percentage points less than the effect for Muslim women. It appears to be more socially acceptable for non-Muslim minority women to work outside the home than for Muslim minority women (among those with preschool children who live in rural areas). The presence of preschool children of either sex decreases non-Muslim minority men's probability of participating in farm work and increases their probability of participating in non-farm work. These effects are muted for non-Muslim men in comparison to Muslim men.

(Insert Table 5 here.)

There is an interesting difference in the effects of school-age girls and boys on their mothers' participation in off-farm work for Muslim and non-Muslim minority womenthe presence in the household of a school-age girl lowers Muslim women's participation in off-farm work but has no equivalent effect for non-Muslim women. Interestingly, for non-Muslim minorities, having a school-age boy decreases both parents' probability of participating in farm work and increases their participation in off-farm work. For women, the increase in the likelihood of off-farm work occurs in both local off-farm work and out migration, while for men the increase shows up only in terms of out migration. 
In the previous section we observed that presence of extra men/potential breadwinners in the household has a significant negative effect on Muslim women's probability of participating in off-farm work. Here we find no equivalent effect. What we rather observe is that the presence of co-resident adults of either sex in the grandparent age range (4670) significantly increases non-Muslim minority women's probability of working outside the county (out migration) and significantly reduces the likelihood that they are involved in farm work.

The estimates of Table 5 also reveal striking differences in effects of household composition between Muslim and non-Muslim minority households. While Muslim women's probability of participating in off-farm work clearly decreases with the presence of any additional adult men, the presence of extra older co-resident adult men, (age 46 and above), raises non-Muslim women's probability of out migration. And while the presence of extra adult women in the household appeared to facilitate Muslim women's off-farm employment, the same is true for non-Muslim women only when the extra women are in the grandparent age range (46-70).

Interestingly while the presence of extra co-resident men and women of the grandparent age range appears to assist/allow both prime-age men and women to migrate out for nonlocal off-farm work, there are gender differences. For men, the increased likelihood of migration seems to come through a reduced likelihood of local off-farm work, while for women the increased likelihood of migration comes from a reduction in probability of farm-work. The estimates of the effects of household composition (in terms of the adults in the household) on types of employment seem to imply more gender neutrality in terms of intergenerational/intra-household allocations among non-Muslim than Muslim minority households.

With respect to individual characteristics, the estimates of Table 5 reveal that women with junior high and higher education levels are significantly less likely to be working in agriculture and much more likely to migrate or to work locally off-farm. The same is true of men. These education effects are stronger for non-Muslim than Muslim minorities. 
While education does not affect the probability of out migration for Muslims, it does increase the probability for non-Muslims of both sexes.

Non-Muslim minority women between the ages of 35 and 39 are more likely than younger women to participate in local off-farm work. A similar pattern is also observed for non-Muslim men of ages 35-45. Being capable of communicating in Mandarin has a significant positive effect on non-Muslim minority women's likelihood of out migration. The differences in individual characteristic effects between Muslim and non-Muslim minorities suggest that employment opportunities in off-farm sectors may be more limited for the former than the latter.

\section{6 c. Rural Han Women and Men}

Table 6 presents the multinomial logit estimates of the marginal effects of factors affecting the occupational choices of the Han women and men in our study. The estimates of household composition variables for Han women and men have a greater degree of similarity to the estimates for their non-Muslim minority counterparts (presented in Table 5) than for their Muslim minority counterparts (presented in Table 4). Specifically, as with non-Muslim minority women, having a preschool girl increases Han women's probability of participating in farm work, while having a preschool boy does not affect their occupational choices. School-age children (of either sex) have no effect on Han women's occupational choices. In contrast, school-age girls increase Muslim women's probability of participating in farm work and decrease their probability of out migration but have no effect on non-Muslim minority women's occupational choices. School-age boys have no effect on Muslim women's occupational choices but decrease non-Muslim minority women's probability of participating in farm work and increase their probability of labor migration. Overall, young children have a greater negative effect on off-farm employment for Muslim minority women than non-Muslim minority and Han women.

With respect to the estimates for men, we note that the patterns of children's effects on Han's men occupational choices are substantively similar to the patterns of Muslim and non-Muslim minority men. Preschool children of either sex and school-age boys 
decrease Han men's probability of participating in farm employment and increase their probability of participating in local off-farm employment. As with Muslim men, schoolage girls have no effect on Han men's occupational choices.

The presence of male breadwinners in the household does not decrease Han women's probability of participating in off-farm employment-a marked difference from our findings for Muslim minority women. Just as we found for non-Muslim minority women, the presence of both mature women and men (age 46 to 70) in the household increases Han women's probability of labor migration, although the effect of mature women's presence is larger than that of mature men's (9.1\% versus 5.1\%). Moreover, the presence of women age 15 to 45 as well as the presence of men age 15 to 24 both increase Han women's probability of out migration. Evidently, the intergenerational relations in nonMuslim households, both minority and Han, are more gender neutral than in Muslim households.

\section{6.d The Effects of Children on Gender Gaps in Employment Type}

As discussed above, we initially expected that children would have differential effects on the off-farm work choices of mothers and fathers, that is, they would negatively affect the off-farm work participation of mothers and positively affect if for fathers. Given the ways that patriarchy can exert itself through cultural and religious norms, we expected that the gap in men's and women's off-farm employment would be greater for Muslims than nonMuslims. When we compare the estimates in Tables 4, 5, and 6 and focus on the effects of preschool children (whether male or female) on their parents' employment choices, we find strong support for this contention, expressed above as part of Hypothesis 1, that the gender-differentiated effect of children on parents' employment choices is greater for Muslims than non-Muslims.

However, we see a much more complex and nuanced set of responses to the presence of school-age children on parents' employment choices. For Muslim women, while the presence of school-age girls significantly increases their likelihood of engaging in farm work and decreases their probability of migrating for work, the presence of school-age 
boys has no such effects. Muslim fathers of sons are significantly less likely to be involved in farming. While non-Muslim minority women's choice of employment type is unaffected by the presence of school-age girls, it is affected by the presence of school-age boys, who reduce their likelihood of farming and increase their likelihood of off-farm work whether local or distant. The presence in the household of a school-age boy reduces the probability of fathers' participation in farming across each of our ethnic groupings. It increases the probability of off-farm work for both groups of non-Muslim men, specifically, of the out-migration of non-Muslim minorities and of the local off-farm employment of the Han.

\section{Conclusions}

We began this research project with its focus on rural households in China's minorityconcentrated areas, wanting to learn how the presence of pre-school and/or school-age children affect the likelihood of their parents' working off-farm -- whether locally or in more distant regions. We explore this question in its larger context, which takes into account not only households' composition and economic characteristics but also individual members' human capital and productive attributes as well as local economic conditions and cultural/religious/ethnic norms. We examine whether this complex set of factors differentially affects members of China’s Muslim and non-Muslim minority ethnic groups and the Han majority. Comparing the role that children play in parents' offfarm work decisions between these three groups provides a window for observing the intersectionality of religious and ethnic norms and gender relations across the domestic and public spheres of work in post-reform rural China.

We find, in accord with traditional gender-role expectations, that children generally decrease women's willingness to work off-farm, that is, away from/outside the home and increase men's willingness to do so. And, focusing on the effects of pre-school children, it does appear to be more socially acceptable for non-Muslim than Muslim women to work away from home, at least for the rural subjects of this study. That is, the gender gap in employment-type choices is wider for Muslim parents than non-Muslim parents. 
When we turn our attention to school-age children, the gender of the child appears to become as important to the analysis as the gender of the parent. One pattern that clearly emerges for school-age children is that in non-Muslim households (both Han and minority), fathers of sons are more likely to work off farm than fathers of daughters. This is also the case for non-Muslim minority mothers of sons. It appears that parents of sons desire higher incomes, perhaps in part in preparation for their educational expenses and perhaps also in preparation for expected expenses associated with their sons' future marriages. According to traditional customs, the groom's family supplies the matrimonial house or apartment. Additionally, bride price (the money given by the groom's family to the bride’s family) has increased rapidly. ${ }^{9}$ That children’s gender affects non-Muslim mothers' off-farm work decisions might be explained by elderly rural people's son preference (Connelly, Roberts and Zheng 2012). Mothers of sons find more support from their mothers-in-law to care for their sons, such that their ability to participate in off-farm work is less constrained than that of mothers of girls.

Turning now to the effects of other issues related to household composition, we find for Muslim households a result analogous to that of Spierings (2014) -- the presence of extra adult men (of any age between 15 and 70) in the household reduces the likelihood that Muslim women are engaged in off-farm work and increases their likelihood of working on the farm. Our findings for the effects of extra adult women in Muslim households are much more muted than those of Spierings. In this regard we find only one significant effect, that is, the presence of a woman of grandmotherly age (between 46 and 70) supports Muslim minority women's ability to engage in distant off-farm work, that is, their ability to migrate for work. For non-Muslim households, grandfathers and grandmothers alike, facilitate the ability of parents (male and female) to migrate for work.

9 News accounts report rural bride prices that vary over time and place: 30,000 RMB in 1999 (Huafeng Sun 2016), 100,000 RMB in 2014 (Peng Zhang, 2014 ), and 200,000 RMB in 2015 (Jianwei Wang, 2015). 


\section{References}

Chang, Hongqin, Xiao-Yuan Dong and Fiona MacPhail. 2011. "Labor Migration and Time Use Patterns of the Left-behind Children and Elderly in Rural China.” World Development 39(12): 2199-2210.

Chang, Hongqin, Fiona MacPhail, and Xiao-Yuan Dong. 2011. "The Feminization of Labor and the Gender Work-Time Gap in Rural China.” Feminist Economics 17(4): 93-124.

Chen, Feinian, Guangya Liu and Christine A. Mair. 2011. "Intergenerational Ties in Context: Grandparents Caring for Grandchildren in China.” Social Forces 90(2): 571-94.

Chen, Zhao, Ming Lu, and Le Xu. 2014. "Returns to dialect." China Economic Review 30:2743. doi: 10.1016/j.chieco.2014.05.006.

Connelly, Rachel and Margaret Maurer-Fazio. 2015. "Labor force participation and hours of work of Western China’s rural elders.” IZA Working Paper 9343.

Connelly, Rachel, and Margaret Maurer-Fazio. 2016. "Left behind, at-risk, and vulnerable elders in rural China." China Economic Review 37:140-153. doi: http://dx.doi.org/10.1016/j.chieco.2015.10.005.

Connelly, Rachel, Kenneth Roberts and Zhenzhen Zheng. 2012. "The Role of Children in the Migration Decisions of Rural Chinese Women.” Journal of Contemporary China 21(73): 93-111.

Connelly, Rachel, Deborah DeGraff, Deborah Levison and Brian McCall. 2006. “Tackling the Endogeneity of Fertility in the Study of Women's Employment in Developing Countries: Alternative Estimation Strategies Using Data from Urban Brazil.” Feminist Economics, 12(4), 561-597.

Croll, Elisabeth. 1995. Changing Identities of Chinese Women: Rhetoric, Experience, and SelfPerception in Twentieth-Century China. (Hong Kong University Press, Zed Books: London and New Jersey.)

Gao, Wenshu, and Russell Smyth. 2011. "Economic returns to speaking 'standard Mandarin' among migrants in China's urban labour market." Economics of Education Review 30 (2):342-352. doi: 10.1016/j.econedurev.2010.11.002. 
Gustafsson, Bjorn, and Sai Ding. 2014. "Why Is There No Income Gap between the Hui Muslim Minority and the Han Majority in Rural Ningxia, China?" The China Quarterly 220 (220):968-987. doi: 10.1017/S0305741014001131.

Gustafsson, Bjorn and Shi Li, “The Ethnic Minority-Majority Income Gap in Rural China During Transition,” Economic Development and Cultural Change, July 2003, Volume 51, Issue 4, pp.805-822.

Gustafsson, Björn, and Yang, Xiuna. 2015. "Are China's Ethnic Minorities Less Likely to Move?" Eurasian geography and economics, 56 (1) p. 44-69

Hannum, Emily and Yu Xie, "Ethnic Stratification in Northwest China: Occupational Differences between Han Chinese and National Minorities in Xinjiang, 1982-1990,” Demography, Volume 35, Issue 3, August 1998, pp.323-333.

Hare, Denise. 1999. 'Push' versus 'pull' factors in migration outflows and returns: Determinants of migration status and spell duration among China's rural population. Journal of Development Studies, 35(3):45-72.

Howell, Anthony, Bjorn Gustasson, and Sai Ding. 2015. "Investigating the patterns and determinants of Han and ethnic Minority Household Migration in China.” Unpublished mimeo.

Howell, Anthony and C. Cindy Fan. 2011. "Migration and Inequality in Xinjiang: a survey of Han and Uyghur Migrants in Urumqi.” Eurasian Geography and economics 52(1): 119139.

Kabeer, Naila. 2008. Mainstreaming Gender in Social Protection for the Informal Economy. London: Commonwealth Secretariat.

Knight, John and Lina Song. 2003. “Chinese Peasant Choices: Migration, Rural Industry or Farming.” Oxford Development Studies 31 (2): 123-147.

Kong, Sherry Tao and Xin Meng. 2010. "The Educational and Health Outcomes of the Children of Migrants." In The Great Migration: Rural-Urban Migration in China and Indonesia, eds. Meng, X., Manning, C., with Li, S., Effendi, T., 135-150. Cheltenham, UK: Edward Elgar Publishing.

Kongar, Ebru, Jennifer C. Olmsted and Elora Shehabuddin. 2014. "Gender and Economics in Muslim Communities: A Critical Feminist and Postcolonial Analysis.” Feminist Economics 20(4): 1-32. 
Lee, Leng, and Xin Meng. 2010. "Why don't more Chinese migrate from the countryside? Institutional constraints and the migration decision." In The Great Migration: RuralUrban Migration in China and Indonesia, eds. Meng, X., Manning, C., with Li, S., Effendi, T., 23-45. Cheltenham, UK: Edward Elgar Publishing Maurer-Fazio, Margaret. 2012. “Ethnic Discrimination in China's Internet Job Board Labor Market,” IZA Journal of Migration. 1:12. DOI: 10.1186/2193-9039-1-12

Maurer-Fazio and Reza Hasmath, "The Contemporary Ethnic Minority in China: An Introduction,” Eurasian Geography and Economics, 2015, pp.1-7. DOI: $10.1080 / 15387216.2015 .1059290$

Maurer-Fazio, Margaret, James Hughes, and Dandan Zhang. 2007. “An Ocean Formed from One Hundred Rivers: The Effects of Ethnicity, Gender, Marriage, and Location on Labor Force Participation in Urban China.” Feminist Economics 13(3/4): 159-87.

Maurer-Fazio, Margaret, James Hughes, and Dandan Zhang. 2010. “A Comparison of ReformEra Labor Force Participation Rates of China’s Ethnic Minorities and Han Majority,” International Journal of Manpower, Volume 31, Number 2, pp. 138-162.

Mackerras, Colin. 2005. “Some Issues of Ethnic and Religious Identity among China’s Islamic Peoples.” Asian Ethnicity, Volume 6, Number 1, pp.3-18.

Mu, Ren, and Dominique Van de Walle. 2011. "Left behind to farm?: women's labor reallocation in rural China." Labour economics 18 (1):83-97. doi: 10.1016/j.labeco.2011.01.009.

Qiao, Fangbin, Scott Rozelle, Linxiu Zhang, Yi Yao, and Jian Zhang. 2015. “Impact of Childcare and Eldercare on Off-farm Activities in Rural China." China \& World Economy 23(2): 100-20.

Sautman, Barry.1998. "Preferential policies for ethnic minorities in China: The case of Xinjiang". Nationalism \& ethnic politics (1353-7113), 4 (1), p. 86-118.

Sautman, Barry. 2010. Scaling back minority rights? the debate about china's ethnic policies. Stanford Journal of International Law 46 (1): 51.

Spierings, Niels. 2014. “The Influence of Patriarchal Norms, Institutions, and Household Composition on Women’s Employment in Twenty-Eight Muslim-Majority Countries.” Feminist Economics 20(4): 87-112. 
Sun, Huafeng. 2016-01-1. "Stories of bride price: 30,000 Yuan for marriage in rural in 1999” Henan Daily Paper. 2 孙华峰《那些年的彩礼故事: 99 年 3 万元在农村完婚》评 2016 年 01 月 12 日 河南日报

Wang, Jianwei. 2015-02-27. “Marriage cost is 200,000 Yuan: working hard for 20 years only for bride price” Qilu Evening Paper，农村娶妻花 20 万: 辛辛苦苦 20 年 一朝彩礼全败 完》2015-02-27 来源: 齐鲁晚报 作者: 王建伟

Zang, Xiaowei. 2008. "Gender and Ethnic Variation in Arranged Marriages in a Chinese City." Journal of Family Issues 29 (5):615-638. doi: 10.1177/0192513X07308039.

Zang, Xiaowei. 2012. “Gender Roles and Ethnic Income Inequality in Urumchi.” Ethnic and racial Studies 35(2): 238-258.

Zhang, Linxiu, Alan de Brauw, and Scott Rozelle. 2004. “China's Rural Labor Market Development and Its Gender Implications.” China Economic Review 15(2): 230-47.

Zhang, Peng. 2014-03-19. “Bride price is above 100,000 in rural: saving for 23 years by youth” China Youth Daily, 张鹏《农村结婚彩礼需十余万元 青年不吃不喝需攒 23 年》2014-03-19 中国青年报

Zhao, Yaohui. 1999. "Labor Migration and Earning Differences: The Case of Rural China.” Economic Development and Cultural Change 47(4): 767-82. 
Table 1 Household Income, Poverty Rates, and Employment Patterns, by Gender

\begin{tabular}{|l|l|l|l|l|l|l}
\hline & \multicolumn{3}{|c|}{ Muslim } & \multicolumn{2}{c|}{$\begin{array}{l}\text { Non-Muslim } \\
\text { Minority }\end{array}$} & \multicolumn{2}{c}{ Han } \\
\hline & Women & Men & Women & Men & Women & Men \\
\hline $\begin{array}{l}\text { Per capita annual } \\
\text { household income (yuan) }\end{array}$ & 5,835 & 5,796 & 4,688 & 4,532 & 7,760 & 7,731 \\
\hline Poverty rate (\%) & 19.1 & 19.3 & 20.9 & 21.6 & 9.2 & 9.5 \\
\hline Distribution of occupational/employment type (\%) \\
\hline Farm work & 77.6 & 21.2 & 59.4 & 23.1 & 70.2 & 28.9 \\
\hline Local off-farm work & 14.5 & 44.2 & 22.8 & 46.9 & 18.6 & 48.0 \\
\hline $\begin{array}{l}\text { Nonlocal off-farm } \\
\text { work/migration }\end{array}$ & 7.9 & 34.6 & 17.8 & 30.0 & 11.2 & 23.1 \\
\hline Number of observations & 897 & 916 & 1,798 & 1,777 & 1,477 & 1,514 \\
\hline
\end{tabular}

Note: Poverty is defined here as annual income below 2,300 yuan per person.

Source: China Household Ethnicity Survey 2012. 
Table 2 Household Size and Composition by Gender and Age

\begin{tabular}{|c|c|c|c|c|c|c|}
\hline & \multicolumn{2}{|c|}{ Muslim } & \multicolumn{2}{|c|}{$\begin{array}{l}\text { Non-Muslim } \\
\text { Minority }\end{array}$} & \multicolumn{2}{|c|}{ Han } \\
\hline & Women & Men & Women & Men & Women & Men \\
\hline Number of household members & 5.36 & 5.49 & 5.12 & 5.14 & 4.74 & 4.72 \\
\hline Number of children aged 0-5 & 0.67 & 0.73 & 0.47 & 0.48 & 0.41 & 0.40 \\
\hline Number of children aged 6-14 & 0.83 & 0.84 & 0.63 & 0.63 & 0.64 & 0.63 \\
\hline Number of children aged 0-14 & 1.50 & 1.56 & 1.10 & 1.11 & 1.05 & 1.03 \\
\hline \multicolumn{7}{|l|}{ \% household children of age: } \\
\hline Girl(s) age $0-5$ & 26.3 & 28.3 & 18.4 & 18.6 & 16.1 & 15.9 \\
\hline Boy(s) age $0-5$ & 32.1 & 33.6 & 25.5 & 26.3 & 21.8 & 20.7 \\
\hline Girl(s) age 6-14 & 36.5 & 36.4 & 26.4 & 27.0 & 30.2 & 29.6 \\
\hline Boy(s) age 6-14 & 36.9 & 37.0 & 34.2 & 34.7 & 32.8 & 33.2 \\
\hline \% Households with Disabled Persons & 6.4 & 6.4 & 4.8 & 5.1 & 4.1 & 3.9 \\
\hline \multicolumn{7}{|c|}{ \% Households with Members of Particular Age and Gender Composition } \\
\hline Women age $15-24$ & 47.6 & 47.7 & 38.7 & 38.0 & 36.3 & 36.3 \\
\hline Men age 15-24 & 41.7 & 41.5 & 36.0 & 35.6 & 33.2 & 34.1 \\
\hline Women age $25-45$ & 77.7 & 76.5 & 87.2 & 87.0 & 89.9 & 89.3 \\
\hline Men age 25-45 & 84.2 & 85.0 & 91.8 & 92.1 & 93.8 & 94.6 \\
\hline Women age $46-70$ & 34.6 & 36.2 & 44.0 & 45.3 & 37.1 & 36.7 \\
\hline Men age 46-70 & 35.2 & 35.4 & 42.3 & 38.9 & 35.4 & 34.8 \\
\hline Women over age 70 & 6.0 & 6.3 & 11.4 & 11.1 & 6.4 & 6.8 \\
\hline Men over age 70 & 8.4 & 8.4 & 9.6 & 9.6 & 5.3 & 5.5 \\
\hline Number of Observations & 896 & 916 & 1,798 & 1,777 & 1,477 & 1,514 \\
\hline
\end{tabular}

Source: China Household Ethnicity Survey 2012. 
Table 3 Education, Language Capability, and Social Networks/Means of Finding Employment, by Gender

\begin{tabular}{|c|c|c|c|c|c|c|}
\hline & \multicolumn{2}{|c|}{ Muslim } & \multicolumn{2}{|c|}{$\begin{array}{l}\text { Non-Muslim } \\
\text { Minority }\end{array}$} & \multicolumn{2}{|c|}{ Han } \\
\hline & Women & Men & Women & Men & Women & Men \\
\hline \multicolumn{7}{|l|}{ Education (\%) } \\
\hline Primary or below & 58.2 & 46.0 & 49.4 & 32.3 & 33.8 & 25.0 \\
\hline Junior high school & 34.2 & 42.6 & 45.5 & 57.7 & 56.8 & 61.9 \\
\hline Senior high school or higher & 7.6 & 11.4 & 5.1 & 10.0 & 9.4 & 13.1 \\
\hline \multicolumn{7}{|l|}{ Language (\%) } \\
\hline $\begin{array}{l}\text { Can communicate in Mandarin } \\
\text { (Putonghua) or local Han } \\
\text { dialect }\end{array}$ & 33.0 & 37.4 & 43.1 & 49.2 & 100.0 & 1.00 \\
\hline \multicolumn{7}{|c|}{ Networks used/means of finding local off-farm work (\%) } \\
\hline Government arrangement & 6.6 & 5.5 & 3.5 & 1.8 & 4.6 & 4.6 \\
\hline Employment agency & 1.1 & 1.3 & 2.6 & 3.4 & 3.3 & 2.7 \\
\hline Direct application & 7.9 & 3.0 & 4.4 & 4.8 & 4.6 & 3.8 \\
\hline Family and relatives & 41.6 & 19.5 & 28.8 & 23.6 & 22.5 & 23.7 \\
\hline Friends and acquaintances & 38.2 & 59.3 & 52.0 & 58.7 & 56.3 & 58.5 \\
\hline Other & 4.5 & 11.4 & 8.7 & 7.7 & 8.6 & 6.7 \\
\hline \multicolumn{7}{|c|}{ Networks used/means of finding nonlocal off-farm work/migration (\%) } \\
\hline Government arrangement & 2.2 & 1.5 & 0.4 & 0.8 & 1.2 & 0.8 \\
\hline Employment agency & 2.2 & 1.7 & 1.0 & 1.7 & 7.0 & 4.9 \\
\hline Direct application & 6.5 & 5.5 & 2.5 & 1.7 & 1.2 & 1.6 \\
\hline Family and relatives & 47.8 & 33.2 & 30.1 & 23.9 & 36.0 & 28.9 \\
\hline Friends and acquaintances & 37.0 & 50.7 & 60.0 & 64.2 & 50.4 & 58.9 \\
\hline Others & 4.4 & 7.4 & 6.0 & 7.7 & 4.1 & 5.1 \\
\hline No. observations & 896 & 916 & 1,798 & 1,777 & 1,477 & 1,514 \\
\hline
\end{tabular}

Source: China Household Ethnicity Survey 2012. 
Table 4 Multinomial Logit Estimates of Occupational Choice for Muslim Women and Muslim Men (Marginal Effects)

\begin{tabular}{|c|c|c|c|c|c|c|}
\hline & \multicolumn{3}{|c|}{ Women } & \multicolumn{3}{|c|}{ Men } \\
\hline & Farm Work & $\begin{array}{c}\text { Local } \\
\text { Off-farm Work }\end{array}$ & $\begin{array}{c}\text { Nonlocal } \\
\text { Off-farm Work }\end{array}$ & Farm Work & $\begin{array}{c}\text { Local } \\
\text { Off-farm Work }\end{array}$ & $\begin{array}{c}\text { Nonlocal } \\
\text { Off-farm Work }\end{array}$ \\
\hline $\begin{array}{l}\text { Girl(s) } 0-5 \\
\text { in household }\end{array}$ & $\begin{array}{l}0.116 \\
(0.033)^{* * *}\end{array}$ & $\begin{array}{r}-0.047 \\
(0.030) \\
\end{array}$ & $\begin{array}{l}-0.069 \\
(0.022)^{* * *}\end{array}$ & $\begin{array}{l}-0.090 \\
(0.031)^{* * *}\end{array}$ & $\begin{array}{l}0.124 \\
(0.035)^{* * *} \\
\end{array}$ & $\begin{array}{c}-0.034 \\
(0.029) \\
\end{array}$ \\
\hline $\begin{array}{l}\text { Boy(s) 0-5 } \\
\text { in household }\end{array}$ & $\begin{array}{l}0.114 \\
(0.032)^{* * *}\end{array}$ & $\begin{array}{c}-0.046 \\
(0.028)\end{array}$ & $\begin{array}{l}-0.068 \\
(0.020)^{* * *}\end{array}$ & $\begin{array}{l}-0.087 \\
(0.031)^{* * *}\end{array}$ & $\begin{array}{l}0.130 \\
(0.034)^{* * *}\end{array}$ & $\begin{array}{c}-0.043 \\
(0.028)\end{array}$ \\
\hline $\begin{array}{l}\text { Girl(s) 6-14 } \\
\text { in household }\end{array}$ & $\begin{array}{l}0.073 \\
(0.030)^{* *} \\
\end{array}$ & $\begin{array}{r}-0.020 \\
(0.025) \\
\end{array}$ & $\begin{array}{l}-0.052 \\
(0.021)^{* *} \\
\end{array}$ & $\begin{array}{l}0.010 \\
(0.028) \\
\end{array}$ & $\begin{array}{r}-0.012 \\
(0.033) \\
\end{array}$ & $\begin{array}{l}0.002 \\
(0.029) \\
\end{array}$ \\
\hline $\begin{array}{l}\text { Boy(s) 6-14 } \\
\text { in household }\end{array}$ & $\begin{array}{l}0.020 \\
(0.030) \\
\end{array}$ & $\begin{array}{r}-0.019 \\
(0.026) \\
\end{array}$ & $\begin{array}{r}-0.001 \\
(0.020) \\
\end{array}$ & $\begin{array}{c}-0.053 \\
(0.031)^{*}\end{array}$ & $\begin{array}{l}0.044 \\
(0.035) \\
\end{array}$ & $\begin{array}{l}0.008 \\
(0.029) \\
\end{array}$ \\
\hline $\begin{array}{l}\text { Disabled in } \\
\text { household }\end{array}$ & $\begin{array}{r}-0.012 \\
(0.051) \\
\end{array}$ & $\begin{array}{l}0.038 \\
(0.043) \\
\end{array}$ & $\begin{array}{r}-0.026 \\
(0.035) \\
\end{array}$ & $\begin{array}{l}0.110 \\
(0.046)^{* *}\end{array}$ & $\begin{array}{r}-0.034 \\
(0.058) \\
\end{array}$ & $\begin{array}{c}-0.076 \\
(0.048) \\
\end{array}$ \\
\hline $\begin{array}{l}\text { Female 15-24 } \\
\text { in household }\end{array}$ & $\begin{array}{l}0.018 \\
(0.037) \\
\end{array}$ & $\begin{array}{r}-0.026 \\
(0.031) \\
\end{array}$ & $\begin{array}{l}0.008 \\
(0.025) \\
\end{array}$ & $\begin{array}{r}-0.007 \\
(0.033)\end{array}$ & $\begin{array}{r}-0.033 \\
(0.039) \\
\end{array}$ & $\begin{array}{l}0.040 \\
(0.033) \\
\end{array}$ \\
\hline $\begin{array}{l}\text { Male 15-24 } \\
\text { in household }\end{array}$ & $\begin{array}{l}0.067 \\
(0.036)^{*}\end{array}$ & $\begin{array}{l}-0.069 \\
(0.032)^{* *}\end{array}$ & $\begin{array}{l}0.002 \\
(0.024) \\
\end{array}$ & $\begin{array}{r}-0.017 \\
(0.034)\end{array}$ & $\begin{array}{c}-0.008 \\
(0.040)\end{array}$ & $\begin{array}{l}0.024 \\
(0.034) \\
\end{array}$ \\
\hline $\begin{array}{l}\text { Female } 25-45 \\
\text { in household }\end{array}$ & $\begin{array}{l}0.031 \\
(0.064) \\
\end{array}$ & $\begin{array}{c}-0.025 \\
(0.061)\end{array}$ & $\begin{array}{r}-0.006 \\
(0.034)\end{array}$ & $\begin{array}{r}-0.007 \\
(0.046)\end{array}$ & $\begin{array}{l}0.008 \\
(0.053) \\
\end{array}$ & $\begin{array}{c}-0.001 \\
(0.043)\end{array}$ \\
\hline $\begin{array}{l}\text { Male } 25-45 \\
\text { in household }\end{array}$ & $\begin{array}{l}0.121 \\
(0.053)^{* *}\end{array}$ & $\begin{array}{c}-0.114 \\
(0.050)^{* *}\end{array}$ & $\begin{array}{c}-0.007 \\
(0.028) \\
\end{array}$ & $\begin{array}{c}-0.056 \\
(0.060) \\
\end{array}$ & $\begin{array}{r}-0.013 \\
(0.066) \\
\end{array}$ & $\begin{array}{l}0.069 \\
(0.052) \\
\end{array}$ \\
\hline $\begin{array}{l}\text { Female } 46-70 \\
\text { in household }\end{array}$ & $\begin{array}{r}-0.059 \\
(0.041)\end{array}$ & $\begin{array}{r}-0.001 \\
(0.036)\end{array}$ & $\begin{array}{l}0.060 \\
(0.025)^{* *}\end{array}$ & $\begin{array}{l}0.025 \\
(0.039) \\
\end{array}$ & $\begin{array}{c}-0.078 \\
(0.046)^{*} \\
\end{array}$ & $\begin{array}{l}0.053 \\
(0.037) \\
\end{array}$ \\
\hline $\begin{array}{l}\text { Male 46-70 } \\
\text { in household }\end{array}$ & $\begin{array}{l}0.077 \\
(0.043)^{*}\end{array}$ & $\begin{array}{l}-0.099 \\
(0.039)^{* *}\end{array}$ & $\begin{array}{l}0.021 \\
(0.025) \\
\end{array}$ & $\begin{array}{c}-0.008 \\
(0.042) \\
\end{array}$ & $\begin{array}{l}-0.130 \\
(0.047)^{* * *}\end{array}$ & $\begin{array}{l}0.138 \\
(0.037)^{* * *} \\
\end{array}$ \\
\hline Female over 70 & 0.056 & -0.062 & 0.006 & -0.044 & -0.019 & 0.063 \\
\hline
\end{tabular}




\begin{tabular}{|c|c|c|c|c|c|c|}
\hline in household & $(0.055)$ & $(0.048)$ & $(0.035)$ & $(0.063)$ & $(0.068)$ & $(0.047)$ \\
\hline $\begin{array}{l}\text { Male over } 70 \\
\text { in household }\end{array}$ & $\begin{array}{l}0.008 \\
(0.050) \\
\end{array}$ & $\begin{array}{l}0.024 \\
(0.039) \\
\end{array}$ & $\begin{array}{r}-0.032 \\
(0.037) \\
\end{array}$ & $\begin{array}{l}0.014 \\
(0.049) \\
\end{array}$ & $\begin{array}{r}-0.043 \\
(0.058) \\
\end{array}$ & $\begin{array}{l}0.029 \\
(0.047) \\
\end{array}$ \\
\hline $\begin{array}{l}\text { Junior } \\
\text { high school }\end{array}$ & $\begin{array}{c}-0.019 \\
(0.034)\end{array}$ & $\begin{array}{l}0.020 \\
(0.028)\end{array}$ & $\begin{array}{c}-0.001 \\
(0.024)\end{array}$ & $\begin{array}{l}-0.078 \\
(0.029)^{* * *}\end{array}$ & $\begin{array}{l}0.022 \\
(0.034)\end{array}$ & $\begin{array}{l}0.056 \\
(0.030)^{*}\end{array}$ \\
\hline $\begin{array}{l}\text { Senior high } \\
\text { School or higher }\end{array}$ & $\begin{array}{l}-0.158 \\
(0.047)^{* * *}\end{array}$ & $\begin{array}{l}0.110 \\
(0.039)^{* * *}\end{array}$ & $\begin{array}{l}0.048 \\
(0.031)\end{array}$ & $\begin{array}{l}-0.230 \\
(0.053)^{* * *}\end{array}$ & $\begin{array}{l}0.234 \\
(0.054)^{* * *}\end{array}$ & $\begin{array}{r}-0.004 \\
(0.047)\end{array}$ \\
\hline Age 25-29 & $\begin{array}{r}-0.103 \\
(0.063)\end{array}$ & $\begin{array}{l}0.058 \\
(0.059)\end{array}$ & $\begin{array}{l}0.045 \\
(0.033)\end{array}$ & $\begin{array}{l}0.025 \\
(0.059)\end{array}$ & $\begin{array}{r}-0.060 \\
(0.065)\end{array}$ & $\begin{array}{l}0.035 \\
(0.050)\end{array}$ \\
\hline Age 30-24 & $\begin{array}{l}-0.187 \\
(0.070)^{* * *}\end{array}$ & $\begin{array}{l}0.119 \\
(0.066)^{*}\end{array}$ & $\begin{array}{l}0.068 \\
(0.038)^{*}\end{array}$ & $\begin{array}{l}0.040 \\
(0.071)\end{array}$ & $\begin{array}{c}-0.040 \\
(0.078)\end{array}$ & $\begin{array}{l}0.000 \\
(0.061)\end{array}$ \\
\hline Age 35-39 & $\begin{array}{l}-0.175 \\
(0.069)^{* *}\end{array}$ & $\begin{array}{l}0.167 \\
(0.065)^{* * *}\end{array}$ & $\begin{array}{l}0.008 \\
(0.039)\end{array}$ & $\begin{array}{l}0.024 \\
(0.069)\end{array}$ & $\begin{array}{c}-0.035 \\
(0.076)\end{array}$ & $\begin{array}{l}0.011 \\
(0.060)\end{array}$ \\
\hline Age 40-45 & $\begin{array}{r}-0.080 \\
(0.075)\end{array}$ & $\begin{array}{l}0.121 \\
(0.068)^{*}\end{array}$ & $\begin{array}{c}-0.041 \\
(0.047)\end{array}$ & $\begin{array}{l}0.042 \\
(0.070)\end{array}$ & $\begin{array}{l}0.062 \\
(0.078)\end{array}$ & $\begin{array}{l}-0.104 \\
(0.062) *\end{array}$ \\
\hline $\begin{array}{l}\text { Able to speak } \\
\text { Mandarin }\end{array}$ & $\begin{array}{l}0.040 \\
(0.037)\end{array}$ & $\begin{array}{r}-0.031 \\
(0.032)\end{array}$ & $\begin{array}{r}-0.008 \\
(0.024) \\
\end{array}$ & $\begin{array}{l}0.048 \\
(0.042)\end{array}$ & $\begin{array}{c}-0.056 \\
(0.045)\end{array}$ & $\begin{array}{l}0.009 \\
(0.034)\end{array}$ \\
\hline $\begin{array}{l}\text { Household assets } \\
\text { income }\end{array}$ & $\begin{array}{l}0.130 \\
(0.094) \\
\end{array}$ & $\begin{array}{c}-0.031 \\
(0.046) \\
\end{array}$ & $\begin{array}{r}-0.100 \\
(0.104) \\
\end{array}$ & $\begin{array}{r}-0.018 \\
(0.053)\end{array}$ & $\begin{array}{l}0.069 \\
(0.063)\end{array}$ & $\begin{array}{c}-0.051 \\
(0.068)\end{array}$ \\
\hline $\begin{array}{l}\text { Distance to } \\
\text { nearest bus stop }\end{array}$ & $\begin{array}{l}0.008 \\
(0.003)^{* * *}\end{array}$ & $\begin{array}{l}-0.007 \\
(0.002)^{* * *}\end{array}$ & $\begin{array}{r}-0.001 \\
(0.001)\end{array}$ & $\begin{array}{l}0.003 \\
(0.001)^{* *}\end{array}$ & $\begin{array}{l}0.007 \\
(0.002)^{* * *}\end{array}$ & $\begin{array}{l}-0.010 \\
(0.002)^{* * *}\end{array}$ \\
\hline $\begin{array}{l}\text { Village mean per } \\
\text { capita land }\end{array}$ & $\begin{array}{l}0.008 \\
(0.005)^{*}\end{array}$ & $\begin{array}{l}0.000 \\
(0.003) \\
\end{array}$ & $\begin{array}{r}-0.009 \\
(0.005) \\
\end{array}$ & $\begin{array}{l}0.003 \\
(0.002) \\
\end{array}$ & $\begin{array}{l}0.003 \\
(0.003)\end{array}$ & $\begin{array}{l}-0.006 \\
(0.003)^{* *}\end{array}$ \\
\hline $\begin{array}{l}\text { Village mean per } \\
\text { capita income }\end{array}$ & $\begin{array}{c}-0.020 \\
(0.012)^{*}\end{array}$ & $\begin{array}{l}0.019 \\
(0.010)^{*}\end{array}$ & $\begin{array}{l}0.001 \\
(0.007)\end{array}$ & $\begin{array}{l}0.004 \\
(0.013)\end{array}$ & $\begin{array}{l}0.020 \\
(0.014)\end{array}$ & $\begin{array}{l}-0.024 \\
(0.011)^{* *}\end{array}$ \\
\hline $\begin{array}{l}\text { County mean per } \\
\text { capita income }\end{array}$ & $\begin{array}{c}-0.000 \\
(0.002)\end{array}$ & $\begin{array}{l}0.002 \\
(0.002)\end{array}$ & $\begin{array}{r}-0.002 \\
(0.001)\end{array}$ & $\begin{array}{c}-0.003 \\
(0.002)\end{array}$ & $\begin{array}{l}0.006 \\
(0.002)^{* * *}\end{array}$ & $\begin{array}{l}-0.003 \\
(0.002)^{*}\end{array}$ \\
\hline $\begin{array}{l}\text { Share of primary } \\
\text { industry in county } \\
\text { GDP }\end{array}$ & $\begin{array}{l}-0.088 \\
(0.024)^{* * *}\end{array}$ & $\begin{array}{l}0.088 \\
(0.020)^{* * *}\end{array}$ & $\begin{array}{r}-0.000 \\
(0.016)\end{array}$ & $\begin{array}{l}0.016 \\
(0.033)\end{array}$ & $\begin{array}{l}-0.063 \\
(0.037)^{*}\end{array}$ & $\begin{array}{l}0.047 \\
(0.024)^{*}\end{array}$ \\
\hline Village has & 0.040 & -0.052 & 0.012 & 0.083 & -0.128 & 0.045 \\
\hline
\end{tabular}




\begin{tabular}{|c|c|c|c|c|c|c|}
\hline kindergarten & $(0.055)$ & $(0.050)$ & $(0.033)$ & $(0.048)^{*}$ & $(0.063)^{* *}$ & $(0.055)$ \\
\hline $\begin{array}{l}\text { Village has } \\
\text { Primary school }\end{array}$ & $\begin{array}{l}0.045 \\
(0.031) \\
\end{array}$ & $\begin{array}{r}-0.014 \\
(0.027) \\
\end{array}$ & $\begin{array}{c}-0.031 \\
(0.020) \\
\end{array}$ & $\begin{array}{r}-0.003 \\
(0.034) \\
\end{array}$ & $\begin{array}{l}0.007 \\
(0.038) \\
\end{array}$ & $\begin{array}{c}-0.004 \\
(0.032) \\
\end{array}$ \\
\hline $\begin{array}{l}\text { Migrants share of } \\
\text { Village labor force }\end{array}$ & $\begin{array}{r}-0.048 \\
(0.042)\end{array}$ & $\begin{array}{l}0.018 \\
(0.035)\end{array}$ & $\begin{array}{l}0.030 \\
(0.028)\end{array}$ & $\begin{array}{l}0.147 \\
(0.040)^{* * *}\end{array}$ & $\begin{array}{l}-0.228 \\
(0.053) * * *\end{array}$ & $\begin{array}{l}0.081 \\
(0.043)^{*}\end{array}$ \\
\hline Qinghai & $\begin{array}{l}-0.152 \\
(0.056)^{* * *}\end{array}$ & $\begin{array}{l}0.128 \\
(0.050)^{* *}\end{array}$ & $\begin{array}{l}0.024 \\
(0.042)\end{array}$ & $\begin{array}{c}-0.019 \\
(0.031)\end{array}$ & $\begin{array}{l}0.052 \\
(0.050)\end{array}$ & $\begin{array}{c}-0.033 \\
(0.052)\end{array}$ \\
\hline Xinjiang & $\begin{array}{l}0.122 \\
(0.043)^{* * *}\end{array}$ & $\begin{array}{r}-0.034 \\
(0.034)\end{array}$ & $\begin{array}{l}-0.088 \\
(0.030)^{* * *}\end{array}$ & $\begin{array}{l}0.309 \\
(0.050)^{* * *}\end{array}$ & $\begin{array}{l}0.119 \\
(0.054)^{* *}\end{array}$ & $\begin{array}{l}-0.428 \\
(0.042)^{* * *}\end{array}$ \\
\hline $\begin{array}{l}\text { Chi2 } \\
\text { P value }\end{array}$ & $\begin{array}{r}279.42 \\
0.00\end{array}$ & $\begin{array}{r}279.42 \\
0.00\end{array}$ & $\begin{array}{r}279.42 \\
0.00\end{array}$ & $\begin{array}{r}558.97 \\
0.00\end{array}$ & $\begin{array}{r}558.97 \\
0.00\end{array}$ & $\begin{array}{r}558.97 \\
0.00\end{array}$ \\
\hline No. observations & 897 & 897 & 897 & 916 & 916 & 916 \\
\hline
\end{tabular}

${ }^{*} p<0.1 ; * * p<0.05 ; * * * p<0.01$

Source: China Household Ethnicity Survey 2012. 
Table 5 Multinomial Logit Estimates of Occupational Choice for Non-Muslim Minority Women and Men

(Marginal Effects)

\begin{tabular}{|c|c|c|c|c|c|c|}
\hline & \multicolumn{3}{|c|}{ Women } & \multicolumn{3}{|c|}{ Men } \\
\hline & Farm Work & $\begin{array}{c}\text { Local Off-farm } \\
\text { Work }\end{array}$ & $\begin{array}{c}\text { Nonlocal Off-farm } \\
\text { Work }\end{array}$ & Farm Work & $\begin{array}{c}\text { Local Off-farm } \\
\text { Work }\end{array}$ & $\begin{array}{c}\text { Nonlocal Off-farm } \\
\text { Work }\end{array}$ \\
\hline $\begin{array}{l}\text { Girl(s) } 0-5 \\
\text { in household }\end{array}$ & $\begin{array}{l}0.061 \\
(0.031)^{* *}\end{array}$ & $\begin{array}{r}-0.035 \\
(0.029) \\
\end{array}$ & $\begin{array}{r}-0.027 \\
(0.022) \\
\end{array}$ & $\begin{array}{r}-0.040 \\
(0.028) \\
\end{array}$ & $\begin{array}{r}-0.009 \\
(0.032) \\
\end{array}$ & $\begin{array}{l}0.050 \\
(0.026)^{*}\end{array}$ \\
\hline $\begin{array}{l}\text { Boy(s) } 0-5 \\
\text { in household }\end{array}$ & $\begin{array}{r}-0.016 \\
(0.028) \\
\end{array}$ & $\begin{array}{l}0.039 \\
(0.025) \\
\end{array}$ & $\begin{array}{c}-0.023 \\
(0.020) \\
\end{array}$ & $\begin{array}{l}-0.083 \\
(0.026)^{* * *}\end{array}$ & $\begin{array}{l}0.049 \\
(0.029)^{*}\end{array}$ & $\begin{array}{l}0.034 \\
(0.024) \\
\end{array}$ \\
\hline $\begin{array}{l}\text { Girl(s) 6-14 } \\
\text { in household }\end{array}$ & $\begin{array}{l}0.011 \\
(0.027) \\
\end{array}$ & $\begin{array}{l}0.007 \\
(0.024) \\
\end{array}$ & $\begin{array}{c}-0.018 \\
(0.021) \\
\end{array}$ & $\begin{array}{l}-0.070 \\
(0.024)^{* * *}\end{array}$ & $\begin{array}{l}0.030 \\
(0.028) \\
\end{array}$ & $\begin{array}{l}0.040 \\
(0.024) \\
\end{array}$ \\
\hline $\begin{array}{l}\text { Boy(s) 6-14 } \\
\text { in household }\end{array}$ & $\begin{array}{l}-0.085 \\
(0.028)^{* * *}\end{array}$ & $\begin{array}{l}0.043 \\
(0.024)^{*}\end{array}$ & $\begin{array}{l}0.042 \\
(0.021)^{* *}\end{array}$ & $\begin{array}{l}-0.084 \\
(0.024)^{* * *}\end{array}$ & $\begin{array}{l}0.019 \\
(0.028)\end{array}$ & $\begin{array}{l}0.065 \\
(0.024)^{* * *} \\
\end{array}$ \\
\hline $\begin{array}{l}\text { Disabled in } \\
\text { household }\end{array}$ & $\begin{array}{l}0.059 \\
(0.051)\end{array}$ & $\begin{array}{c}-0.026 \\
(0.046)\end{array}$ & $\begin{array}{c}-0.033 \\
(0.039)\end{array}$ & $\begin{array}{r}-0.017 \\
(0.046)\end{array}$ & $\begin{array}{r}-0.046 \\
(0.053)\end{array}$ & $\begin{array}{l}0.063 \\
(0.044)\end{array}$ \\
\hline $\begin{array}{l}\text { Female } 15-24 \\
\text { in household }\end{array}$ & $\begin{array}{l}0.010 \\
(0.030)\end{array}$ & $\begin{array}{l}0.011 \\
(0.025)\end{array}$ & $\begin{array}{c}-0.021 \\
(0.024)\end{array}$ & $\begin{array}{l}0.009 \\
(0.024)\end{array}$ & $\begin{array}{c}-0.016 \\
(0.030)\end{array}$ & $\begin{array}{l}0.007 \\
(0.028)\end{array}$ \\
\hline $\begin{array}{l}\text { Male 15-24 } \\
\text { in household }\end{array}$ & $\begin{array}{r}-0.008 \\
(0.031) \\
\end{array}$ & $\begin{array}{r}-0.013 \\
(0.027) \\
\end{array}$ & $\begin{array}{l}0.020 \\
(0.024) \\
\end{array}$ & $\begin{array}{l}0.012 \\
(0.026) \\
\end{array}$ & $\begin{array}{c}-0.054 \\
(0.032)^{*}\end{array}$ & $\begin{array}{l}0.042 \\
(0.029) \\
\end{array}$ \\
\hline $\begin{array}{l}\text { Female } 25-45 \\
\text { in household }\end{array}$ & $\begin{array}{l}0.005 \\
(0.052)\end{array}$ & $\begin{array}{l}0.002 \\
(0.050)\end{array}$ & $\begin{array}{c}-0.007 \\
(0.036)\end{array}$ & $\begin{array}{l}0.116 \\
(0.041)^{* * *}\end{array}$ & $\begin{array}{c}-0.087 \\
(0.047)^{*}\end{array}$ & $\begin{array}{c}-0.029 \\
(0.037)\end{array}$ \\
\hline $\begin{array}{l}\text { Male 25-45 } \\
\text { in household }\end{array}$ & $\begin{array}{r}-0.087 \\
(0.055)\end{array}$ & $\begin{array}{l}0.072 \\
(0.054)\end{array}$ & $\begin{array}{l}0.015 \\
(0.037)\end{array}$ & $\begin{array}{l}0.030 \\
(0.058)\end{array}$ & $\begin{array}{r}-0.027 \\
(0.071)\end{array}$ & $\begin{array}{r}-0.002 \\
(0.057)\end{array}$ \\
\hline $\begin{array}{l}\text { Female } 46-70 \\
\text { in household }\end{array}$ & $\begin{array}{l}-0.069 \\
(0.031)^{* *} \\
\end{array}$ & $\begin{array}{l}0.010 \\
(0.027) \\
\end{array}$ & $\begin{array}{l}0.059 \\
(0.024)^{* *}\end{array}$ & $\begin{array}{l}0.009 \\
(0.026) \\
\end{array}$ & $\begin{array}{l}-0.073 \\
(0.031)^{* *} \\
\end{array}$ & $\begin{array}{l}0.063 \\
(0.027)^{* *} \\
\end{array}$ \\
\hline $\begin{array}{l}\text { Male 46-70 } \\
\text { In household }\end{array}$ & $\begin{array}{l}-0.099 \\
(0.032)^{* * *}\end{array}$ & $\begin{array}{l}-0.057 \\
(0.028)^{* *} \\
\end{array}$ & $\begin{array}{l}0.156 \\
(0.024)^{* * *}\end{array}$ & $\begin{array}{l}-0.074 \\
(0.028)^{* * *}\end{array}$ & $\begin{array}{l}-0.108 \\
(0.033)^{* * *}\end{array}$ & $\begin{array}{l}0.182 \\
(0.027)^{* * *}\end{array}$ \\
\hline $\begin{array}{l}\text { Female over } 70 \\
\text { in household }\end{array}$ & $\begin{array}{c}-0.030 \\
(0.035)\end{array}$ & $\begin{array}{c}-0.005 \\
(0.031)\end{array}$ & $\begin{array}{l}0.035 \\
(0.027)\end{array}$ & $\begin{array}{c}-0.002 \\
(0.031)\end{array}$ & $\begin{array}{l}0.026 \\
(0.037)\end{array}$ & $\begin{array}{c}-0.024 \\
(0.035)\end{array}$ \\
\hline
\end{tabular}




\begin{tabular}{|c|c|c|c|c|c|c|}
\hline $\begin{array}{l}\text { Male over } 70 \\
\text { in household }\end{array}$ & $\begin{array}{r}-0.045 \\
(0.038)\end{array}$ & $\begin{array}{r}-0.042 \\
(0.034)\end{array}$ & $\begin{array}{l}0.087 \\
(0.027)^{* * *}\end{array}$ & $\begin{array}{r}-0.028 \\
(0.034)\end{array}$ & $\begin{array}{r}-0.031 \\
(0.039)\end{array}$ & $\begin{array}{l}0.059 \\
(0.035)^{*}\end{array}$ \\
\hline $\begin{array}{l}\text { Junior } \\
\text { high school }\end{array}$ & $\begin{array}{l}-0.098 \\
(0.025)^{* * *}\end{array}$ & $\begin{array}{l}0.050 \\
(0.023)^{* *}\end{array}$ & $\begin{array}{l}0.049 \\
(0.019)^{* *}\end{array}$ & $\begin{array}{c}-0.035 \\
(0.021)^{*}\end{array}$ & $\begin{array}{r}-0.003 \\
(0.026)\end{array}$ & $\begin{array}{l}0.039 \\
(0.023)^{*}\end{array}$ \\
\hline $\begin{array}{l}\text { Senior high } \\
\text { School or higher }\end{array}$ & $\begin{array}{l}-0.164 \\
(0.053)^{* * *}\end{array}$ & $\begin{array}{l}0.127 \\
(0.044)^{* * *}\end{array}$ & $\begin{array}{l}0.037 \\
(0.041)\end{array}$ & $\begin{array}{l}-0.262 \\
(0.053)^{* * *}\end{array}$ & $\begin{array}{l}0.187 \\
(0.048)^{* * *}\end{array}$ & $\begin{array}{l}0.075 \\
(0.039)^{*}\end{array}$ \\
\hline Age 25-29 & $\begin{array}{r}-0.068 \\
(0.054)\end{array}$ & $\begin{array}{l}0.032 \\
(0.052)\end{array}$ & $\begin{array}{l}0.036 \\
(0.037) \\
\end{array}$ & $\begin{array}{r}-0.087 \\
(0.055)\end{array}$ & $\begin{array}{l}0.050 \\
(0.068)\end{array}$ & $\begin{array}{l}0.036 \\
(0.056) \\
\end{array}$ \\
\hline Age 30-24 & $\begin{array}{r}-0.097 \\
(0.060)\end{array}$ & $\begin{array}{l}0.051 \\
(0.057)\end{array}$ & $\begin{array}{l}0.047 \\
(0.043)\end{array}$ & $\begin{array}{c}-0.096 \\
(0.058)^{*}\end{array}$ & $\begin{array}{l}0.030 \\
(0.073)\end{array}$ & $\begin{array}{l}0.066 \\
(0.062)\end{array}$ \\
\hline Age 35-39 & $\begin{array}{l}-0.128 \\
(0.059)^{* *}\end{array}$ & $\begin{array}{l}0.114 \\
(0.055)^{* *}\end{array}$ & $\begin{array}{l}0.014 \\
(0.043)\end{array}$ & $\begin{array}{l}-0.132 \\
(0.056)^{* *}\end{array}$ & $\begin{array}{l}0.121 \\
(0.071)^{*}\end{array}$ & $\begin{array}{l}0.011 \\
(0.062)\end{array}$ \\
\hline Age $40-45$ & $\begin{array}{r}-0.064 \\
(0.060)\end{array}$ & $\begin{array}{l}0.085 \\
(0.056)\end{array}$ & $\begin{array}{r}-0.021 \\
(0.047)\end{array}$ & $\begin{array}{l}-0.126 \\
(0.055)^{* *}\end{array}$ & $\begin{array}{l}0.152 \\
(0.071)^{* *}\end{array}$ & $\begin{array}{r}-0.026 \\
(0.063)\end{array}$ \\
\hline $\begin{array}{l}\text { Able to speak } \\
\text { Mandarin }\end{array}$ & $\begin{array}{c}-0.051 \\
(0.023)^{* *}\end{array}$ & $\begin{array}{l}0.016 \\
(0.020)\end{array}$ & $\begin{array}{l}0.035 \\
(0.017)^{* *}\end{array}$ & $\begin{array}{l}-0.052 \\
(0.019)^{* * *}\end{array}$ & $\begin{array}{l}0.023 \\
(0.023)\end{array}$ & $\begin{array}{l}0.029 \\
(0.020)\end{array}$ \\
\hline $\begin{array}{l}\text { Household assets } \\
\text { income }\end{array}$ & $\begin{array}{l}0.092 \\
(0.073) \\
\end{array}$ & $\begin{array}{l}0.046 \\
(0.041) \\
\end{array}$ & $\begin{array}{r}-0.138 \\
(0.098) \\
\end{array}$ & $\begin{array}{l}0.012 \\
(0.025) \\
\end{array}$ & $\begin{array}{l}0.023 \\
(0.042) \\
\end{array}$ & $\begin{array}{r}-0.035 \\
(0.054) \\
\end{array}$ \\
\hline $\begin{array}{l}\text { Distance to } \\
\text { nearest bus stop }\end{array}$ & $\begin{array}{l}0.003 \\
(0.001)^{* * *}\end{array}$ & $\begin{array}{l}-0.002 \\
(0.001)^{* * *}\end{array}$ & $\begin{array}{r}-0.000 \\
(0.001)\end{array}$ & $\begin{array}{r}-0.000 \\
(0.001)\end{array}$ & $\begin{array}{l}0.000 \\
(0.001)\end{array}$ & $\begin{array}{r}-0.000 \\
(0.001)\end{array}$ \\
\hline $\begin{array}{l}\text { Village mean per } \\
\text { capita land }\end{array}$ & $\begin{array}{l}0.002 \\
(0.002) \\
\end{array}$ & $\begin{array}{r}-0.002 \\
(0.001) \\
\end{array}$ & $\begin{array}{r}-0.001 \\
(0.002) \\
\end{array}$ & $\begin{array}{l}0.004 \\
(0.002)^{* *}\end{array}$ & $\begin{array}{l}0.002 \\
(0.004)\end{array}$ & $\begin{array}{r}-0.006 \\
(0.005)\end{array}$ \\
\hline $\begin{array}{l}\text { Village mean per } \\
\text { capita income }\end{array}$ & $\begin{array}{r}-0.007 \\
(0.008)\end{array}$ & $\begin{array}{l}0.005 \\
(0.007)\end{array}$ & $\begin{array}{l}0.002 \\
(0.006)\end{array}$ & $\begin{array}{r}-0.010 \\
(0.006)\end{array}$ & $\begin{array}{l}0.004 \\
(0.008)\end{array}$ & $\begin{array}{l}0.006 \\
(0.007)\end{array}$ \\
\hline $\begin{array}{l}\text { County mean per } \\
\text { capita income }\end{array}$ & $\begin{array}{l}0.003 \\
(0.002)^{*}\end{array}$ & $\begin{array}{l}0.000 \\
(0.001)\end{array}$ & $\begin{array}{r}-0.003 \\
(0.002)\end{array}$ & $\begin{array}{l}0.004 \\
(0.001)^{* * *}\end{array}$ & $\begin{array}{l}0.007 \\
(0.002)^{* * *}\end{array}$ & $\begin{array}{c}-0.011 \\
(0.003)^{* * *}\end{array}$ \\
\hline $\begin{array}{l}\text { Share of primary } \\
\text { industry in county } \\
\text { GDP }\end{array}$ & $\begin{array}{l}0.594 \\
(0.184)^{* * *}\end{array}$ & $\begin{array}{l}-0.412 \\
(0.162)^{* *}\end{array}$ & $\begin{array}{r}-0.182 \\
(0.145)\end{array}$ & $\begin{array}{l}0.028 \\
(0.156)\end{array}$ & $\begin{array}{l}0.668 \\
(0.189)^{* * *}\end{array}$ & $\begin{array}{l}-0.696 \\
(0.170)^{* * *}\end{array}$ \\
\hline $\begin{array}{l}\text { Village has } \\
\text { kindergarten }\end{array}$ & $\begin{array}{r}-0.007 \\
(0.030)\end{array}$ & $\begin{array}{l}0.049 \\
(0.025)^{*}\end{array}$ & $\begin{array}{c}-0.042 \\
(0.024)^{*}\end{array}$ & $\begin{array}{r}-0.017 \\
(0.025)\end{array}$ & $\begin{array}{l}0.006 \\
(0.030)\end{array}$ & $\begin{array}{l}0.011 \\
(0.027)\end{array}$ \\
\hline
\end{tabular}




\begin{tabular}{|c|c|c|c|c|c|c|}
\hline $\begin{array}{l}\text { Village has } \\
\text { Primary school }\end{array}$ & $\begin{array}{r}-0.023 \\
(0.026) \\
\end{array}$ & $\begin{array}{l}0.011 \\
(0.023)\end{array}$ & $\begin{array}{l}0.013 \\
(0.020)\end{array}$ & $\begin{array}{c}-0.010 \\
(0.022)\end{array}$ & $\begin{array}{c}-0.018 \\
(0.027)\end{array}$ & $\begin{array}{l}0.029 \\
(0.024)\end{array}$ \\
\hline $\begin{array}{l}\text { Migrants share of } \\
\text { Village labor force }\end{array}$ & $\begin{array}{l}-0.129 \\
(0.038)^{* * *}\end{array}$ & $\begin{array}{l}0.026 \\
(0.033)\end{array}$ & $\begin{array}{l}0.103 \\
(0.026)^{* * *}\end{array}$ & $\begin{array}{l}-0.066 \\
(0.033)^{* *}\end{array}$ & $\begin{array}{c}-0.040 \\
(0.038)\end{array}$ & $\begin{array}{l}0.106 \\
(0.032)^{* * *}\end{array}$ \\
\hline Inner Mongolia & $\begin{array}{l}0.171 \\
(0.168)\end{array}$ & $\begin{array}{c}-0.215 \\
(0.166)\end{array}$ & $\begin{array}{l}0.044 \\
(0.030)\end{array}$ & $\begin{array}{l}0.080 \\
(0.149)\end{array}$ & $\begin{array}{l}0.373 \\
(0.059) * * *\end{array}$ & $\begin{array}{l}-0.453 \\
(0.158)^{* * *}\end{array}$ \\
\hline Human & $\begin{array}{c}-0.054 \\
(0.166)\end{array}$ & $\begin{array}{r}-0.107 \\
(0.166)\end{array}$ & $\begin{array}{l}0.161 \\
(0.018)^{* * *}\end{array}$ & $\begin{array}{l}0.009 \\
(0.144)\end{array}$ & $\begin{array}{l}0.460 \\
(0.027)^{* * *}\end{array}$ & $\begin{array}{l}-0.469 \\
(0.143)^{* * *}\end{array}$ \\
\hline Guangxi & $\begin{array}{c}-0.112 \\
(0.165)\end{array}$ & $\begin{array}{r}-0.079 \\
(0.164)\end{array}$ & $\begin{array}{l}0.191 \\
(0.021)^{* * *}\end{array}$ & $\begin{array}{c}-0.032 \\
(0.142)\end{array}$ & $\begin{array}{l}0.368 \\
(0.025)^{* * *}\end{array}$ & $\begin{array}{c}-0.335 \\
(0.143)^{* *}\end{array}$ \\
\hline Guizhou & $\begin{array}{c}-0.159 \\
(0.164)\end{array}$ & $\begin{array}{c}-0.067 \\
(0.164)\end{array}$ & $\begin{array}{l}0.226 \\
(0.017)^{* * *}\end{array}$ & $\begin{array}{c}-0.084 \\
(0.141)\end{array}$ & $\begin{array}{l}0.492 \\
(0.021)^{* * * *}\end{array}$ & $\begin{array}{c}-0.408 \\
(0.141)^{* * *}\end{array}$ \\
\hline Qinghai & $\begin{array}{r}-0.134 \\
(0.169)\end{array}$ & $\begin{array}{l}0.076 \\
(0.169)\end{array}$ & $\begin{array}{l}0.058 \\
(0.019)^{* * *}\end{array}$ & $\begin{array}{c}-0.159 \\
(0.142)\end{array}$ & $\begin{array}{l}0.711 \\
(0.035)^{* * *}\end{array}$ & $\begin{array}{l}-0.552 \\
(0.144)^{* * *}\end{array}$ \\
\hline Xinjiang & $\begin{array}{c}-0.009 \\
(0.300)\end{array}$ & $\begin{array}{l}0.009 \\
(0.300)\end{array}$ & $\begin{array}{l}0.000 \\
(0.003)\end{array}$ & $\begin{array}{c}-0.067 \\
(0.232)\end{array}$ & $\begin{array}{l}0.276 \\
(0.202)\end{array}$ & $\begin{array}{c}-0.209 \\
(0.302)\end{array}$ \\
\hline $\begin{array}{l}\text { Chi2 } \\
\text { P value }\end{array}$ & $\begin{array}{r}465.24 \\
0.00\end{array}$ & $\begin{array}{r}465.24 \\
0.00\end{array}$ & $\begin{array}{r}465.24 \\
0.00\end{array}$ & $\begin{array}{r}564.22 \\
0.00\end{array}$ & $\begin{array}{r}564.22 \\
0.00\end{array}$ & $\begin{array}{r}564.22 \\
0.00\end{array}$ \\
\hline No. observations & 1,798 & 1,798 & 1,798 & 1,777 & 1,777 & 1,777 \\
\hline
\end{tabular}

${ }^{*} p<0.1 ; * * p<0.05 ; * * * p<0.01$

Source: China Household Ethnicity Survey 2012. 
Table 6 Multinomial Logit Estimates of Occupational Choice for Han Women and Han Men

(Marginal Effects)

\begin{tabular}{|c|c|c|c|c|c|c|}
\hline & \multicolumn{3}{|c|}{ Women } & \multicolumn{3}{|c|}{ Men } \\
\hline & Farm Work & $\begin{array}{c}\text { Local Off-farm } \\
\text { Work }\end{array}$ & $\begin{array}{c}\text { Nonlocal Off-farm } \\
\text { Work }\end{array}$ & Farm Work & $\begin{array}{c}\text { Local Off-farm } \\
\text { Work }\end{array}$ & $\begin{array}{c}\text { Nonlocal Off-farm } \\
\text { Work }\end{array}$ \\
\hline $\begin{array}{l}\text { Girl(s) } 0-5 \\
\text { in household }\end{array}$ & $\begin{array}{l}0.099 \\
(0.034)^{* * *}\end{array}$ & $\begin{array}{c}-0.060 \\
(0.032)^{*}\end{array}$ & $\begin{array}{c}-0.039 \\
(0.021)^{*}\end{array}$ & $\begin{array}{c}-0.066 \\
(0.034)^{*}\end{array}$ & $\begin{array}{l}0.075 \\
(0.039)^{*}\end{array}$ & $\begin{array}{r}-0.010 \\
(0.028) \\
\end{array}$ \\
\hline $\begin{array}{l}\text { Boy(s) } 0-5 \\
\text { in household }\end{array}$ & $\begin{array}{l}0.048 \\
(0.031) \\
\end{array}$ & $\begin{array}{c}-0.038 \\
(0.029) \\
\end{array}$ & $\begin{array}{r}-0.010 \\
(0.019) \\
\end{array}$ & $\begin{array}{l}-0.081 \\
(0.032)^{* *} \\
\end{array}$ & $\begin{array}{l}0.059 \\
(0.036)^{*}\end{array}$ & $\begin{array}{l}0.022 \\
(0.026)\end{array}$ \\
\hline $\begin{array}{l}\text { Girl(s) 6-14 } \\
\text { in household }\end{array}$ & $\begin{array}{l}0.022 \\
(0.029) \\
\end{array}$ & $\begin{array}{r}-0.040 \\
(0.026) \\
\end{array}$ & $\begin{array}{l}0.017 \\
(0.019) \\
\end{array}$ & $\begin{array}{r}-0.002 \\
(0.027) \\
\end{array}$ & $\begin{array}{l}0.034 \\
(0.032) \\
\end{array}$ & $\begin{array}{r}-0.032 \\
(0.025) \\
\end{array}$ \\
\hline $\begin{array}{l}\text { Boy(s) 6-14 } \\
\text { in household }\end{array}$ & $\begin{array}{c}-0.006 \\
(0.030) \\
\end{array}$ & $\begin{array}{l}0.000 \\
(0.027) \\
\end{array}$ & $\begin{array}{l}0.006 \\
(0.020) \\
\end{array}$ & $\begin{array}{l}-0.120 \\
(0.028)^{* * *}\end{array}$ & $\begin{array}{l}0.133 \\
(0.033)^{* * *}\end{array}$ & $\begin{array}{r}-0.014 \\
(0.025) \\
\end{array}$ \\
\hline $\begin{array}{l}\text { Disabled in } \\
\text { household }\end{array}$ & $\begin{array}{r}-0.006 \\
(0.053)\end{array}$ & $\begin{array}{l}0.045 \\
(0.046)\end{array}$ & $\begin{array}{r}-0.039 \\
(0.038)\end{array}$ & $\begin{array}{l}0.045 \\
(0.057)\end{array}$ & $\begin{array}{l}0.057 \\
(0.065)\end{array}$ & $\begin{array}{c}-0.102 \\
(0.052)^{*}\end{array}$ \\
\hline $\begin{array}{l}\text { Female 15-24 } \\
\text { in household }\end{array}$ & $\begin{array}{r}-0.030 \\
(0.029)\end{array}$ & $\begin{array}{r}-0.019 \\
(0.026)\end{array}$ & $\begin{array}{l}0.050 \\
(0.020)^{* *}\end{array}$ & $\begin{array}{l}0.009 \\
(0.026)\end{array}$ & $\begin{array}{c}-0.053 \\
(0.032)^{*}\end{array}$ & $\begin{array}{l}0.045 \\
(0.025)^{*}\end{array}$ \\
\hline $\begin{array}{l}\text { Male 15-24 } \\
\text { in household }\end{array}$ & $\begin{array}{r}-0.026 \\
(0.032) \\
\end{array}$ & $\begin{array}{r}-0.042 \\
(0.030) \\
\end{array}$ & $\begin{array}{l}0.068 \\
(0.020)^{* * *} \\
\end{array}$ & $\begin{array}{l}0.039 \\
(0.030) \\
\end{array}$ & $\begin{array}{r}-0.050 \\
(0.037) \\
\end{array}$ & $\begin{array}{l}0.011 \\
(0.028) \\
\end{array}$ \\
\hline $\begin{array}{l}\text { Female } 25-45 \\
\text { in household }\end{array}$ & $\begin{array}{r}-0.061 \\
(0.054) \\
\end{array}$ & $\begin{array}{c}-0.022 \\
(0.052) \\
\end{array}$ & $\begin{array}{l}0.082 \\
(0.030)^{* * *}\end{array}$ & $\begin{array}{l}0.055 \\
(0.051) \\
\end{array}$ & $\begin{array}{c}-0.091 \\
(0.056)\end{array}$ & $\begin{array}{l}0.036 \\
(0.037) \\
\end{array}$ \\
\hline $\begin{array}{l}\text { Male 25-45 } \\
\text { in household }\end{array}$ & $\begin{array}{r}-0.049 \\
(0.057)\end{array}$ & $\begin{array}{l}0.008 \\
(0.055)\end{array}$ & $\begin{array}{l}0.040 \\
(0.033)\end{array}$ & $\begin{array}{l}0.075 \\
(0.075)\end{array}$ & $\begin{array}{c}-0.153 \\
(0.084)^{*}\end{array}$ & $\begin{array}{l}0.079 \\
(0.055)\end{array}$ \\
\hline $\begin{array}{l}\text { Female } 46-70 \\
\text { in household } \\
\end{array}$ & $\begin{array}{l}-0.102 \\
(0.035)^{* * *}\end{array}$ & $\begin{array}{l}0.012 \\
(0.032) \\
\end{array}$ & $\begin{array}{l}0.091 \\
(0.024)^{* * *} \\
\end{array}$ & $\begin{array}{r}-0.006 \\
(0.037) \\
\end{array}$ & $\begin{array}{r}-0.045 \\
(0.041) \\
\end{array}$ & $\begin{array}{l}0.051 \\
(0.029)^{*}\end{array}$ \\
\hline $\begin{array}{l}\text { Male 46-70 } \\
\text { in household }\end{array}$ & $\begin{array}{r}-0.037 \\
(0.037) \\
\end{array}$ & $\begin{array}{r}-0.013 \\
(0.034)\end{array}$ & $\begin{array}{l}0.051 \\
(0.024)^{* *}\end{array}$ & $\begin{array}{l}0.024 \\
(0.039)\end{array}$ & $\begin{array}{l}-0.108 \\
(0.044)^{* *}\end{array}$ & $\begin{array}{l}0.084 \\
(0.031)^{* * *}\end{array}$ \\
\hline $\begin{array}{l}\text { Female over } 70 \\
\text { in household }\end{array}$ & $\begin{array}{r}-0.039 \\
(0.047)\end{array}$ & $\begin{array}{c}-0.005 \\
(0.042)\end{array}$ & $\begin{array}{l}0.043 \\
(0.034)\end{array}$ & $\begin{array}{l}0.046 \\
(0.042)\end{array}$ & $\begin{array}{r}-0.055 \\
(0.052)\end{array}$ & $\begin{array}{l}0.009 \\
(0.043)\end{array}$ \\
\hline
\end{tabular}




\begin{tabular}{|c|c|c|c|c|c|c|}
\hline $\begin{array}{l}\text { Male over } 70 \\
\text { in household }\end{array}$ & $\begin{array}{l}0.057 \\
(0.051) \\
\end{array}$ & $\begin{array}{r}-0.044 \\
(0.047) \\
\end{array}$ & $\begin{array}{r}-0.013 \\
(0.034) \\
\end{array}$ & $\begin{array}{l}0.008 \\
(0.048) \\
\end{array}$ & $\begin{array}{r}-0.021 \\
(0.057)\end{array}$ & $\begin{array}{l}0.013 \\
(0.043) \\
\end{array}$ \\
\hline $\begin{array}{l}\text { Junior } \\
\text { high school }\end{array}$ & $\begin{array}{r}-0.038 \\
(0.025)\end{array}$ & $\begin{array}{l}0.016 \\
(0.023)\end{array}$ & $\begin{array}{l}0.022 \\
(0.018)\end{array}$ & $\begin{array}{l}-0.095 \\
(0.023)^{* * *}\end{array}$ & $\begin{array}{l}0.069 \\
(0.029)^{* *}\end{array}$ & $\begin{array}{l}0.026 \\
(0.024)\end{array}$ \\
\hline $\begin{array}{l}\text { Senior high } \\
\text { School or higher }\end{array}$ & $\begin{array}{l}-0.115 \\
(0.043)^{* * *}\end{array}$ & $\begin{array}{l}0.059 \\
(0.038)\end{array}$ & $\begin{array}{l}0.056 \\
(0.027)^{* *}\end{array}$ & $\begin{array}{l}-0.357 \\
(0.050)^{* * *}\end{array}$ & $\begin{array}{l}0.306 \\
(0.049)^{* * *}\end{array}$ & $\begin{array}{l}0.052 \\
(0.034)\end{array}$ \\
\hline Age 25-29 & $\begin{array}{r}-0.055 \\
(0.056)\end{array}$ & $\begin{array}{l}0.013 \\
(0.054)\end{array}$ & $\begin{array}{l}0.041 \\
(0.031)\end{array}$ & $\begin{array}{l}0.036 \\
(0.072) \\
\end{array}$ & $\begin{array}{l}0.019 \\
(0.082)\end{array}$ & $\begin{array}{r}-0.055 \\
(0.053)\end{array}$ \\
\hline Age $30-24$ & $\begin{array}{r}-0.010 \\
(0.065)\end{array}$ & $\begin{array}{l}0.021 \\
(0.061)\end{array}$ & $\begin{array}{r}-0.012 \\
(0.038)\end{array}$ & $\begin{array}{r}-0.024 \\
(0.076)\end{array}$ & $\begin{array}{l}0.110 \\
(0.087)\end{array}$ & $\begin{array}{r}-0.086 \\
(0.058)\end{array}$ \\
\hline Age 35-39 & $\begin{array}{r}-0.037 \\
(0.063)\end{array}$ & $\begin{array}{l}0.036 \\
(0.060)\end{array}$ & $\begin{array}{l}0.002 \\
(0.037)\end{array}$ & $\begin{array}{l}0.002 \\
(0.073)\end{array}$ & $\begin{array}{l}0.105 \\
(0.084)\end{array}$ & $\begin{array}{c}-0.107 \\
(0.057)^{*}\end{array}$ \\
\hline Age 40-45 & $\begin{array}{r}-0.010 \\
(0.064)\end{array}$ & $\begin{array}{l}0.077 \\
(0.059)\end{array}$ & $\begin{array}{c}-0.067 \\
(0.040)^{*}\end{array}$ & $\begin{array}{l}0.017 \\
(0.071)\end{array}$ & $\begin{array}{l}0.144 \\
(0.083)^{*}\end{array}$ & $\begin{array}{l}-0.161 \\
(0.057)^{* * *}\end{array}$ \\
\hline $\begin{array}{l}\text { Able to speak } \\
\text { Mandarin }\end{array}$ & $\begin{array}{l}0.000 \\
(0.000)\end{array}$ & $\begin{array}{l}0.000 \\
(0.000)\end{array}$ & $\begin{array}{l}0.000 \\
(0.000)\end{array}$ & $\begin{array}{l}0.000 \\
(0.000)\end{array}$ & $\begin{array}{l}0.000 \\
(0.000)\end{array}$ & $\begin{array}{l}0.000 \\
(0.000)\end{array}$ \\
\hline $\begin{array}{l}\text { Household assets } \\
\text { income }\end{array}$ & $\begin{array}{l}0.006 \\
(0.019) \\
\end{array}$ & $\begin{array}{r}-0.005 \\
(0.016) \\
\end{array}$ & $\begin{array}{r}-0.000 \\
(0.020) \\
\end{array}$ & $\begin{array}{l}0.025 \\
(0.014)^{*}\end{array}$ & $\begin{array}{l}0.019 \\
(0.030) \\
\end{array}$ & $\begin{array}{c}-0.044 \\
(0.039)\end{array}$ \\
\hline $\begin{array}{l}\text { Distance to } \\
\text { nearest bus stop }\end{array}$ & $\begin{array}{l}0.003 \\
(0.001)^{* * *}\end{array}$ & $\begin{array}{r}-0.001 \\
(0.001)\end{array}$ & $\begin{array}{l}-0.001 \\
(0.001)^{* *}\end{array}$ & $\begin{array}{l}0.001 \\
(0.001)\end{array}$ & $\begin{array}{l}0.001 \\
(0.001)\end{array}$ & $\begin{array}{l}-0.002 \\
(0.001)^{* * *}\end{array}$ \\
\hline $\begin{array}{l}\text { Village mean per } \\
\text { capita land }\end{array}$ & $\begin{array}{l}0.019 \\
(0.005)^{* * *}\end{array}$ & $\begin{array}{l}-0.013 \\
(0.005)^{* * *}\end{array}$ & $\begin{array}{r}-0.007 \\
(0.005) \\
\end{array}$ & $\begin{array}{l}0.013 \\
(0.003)^{* * *}\end{array}$ & $\begin{array}{l}-0.010 \\
(0.004)^{* *}\end{array}$ & $\begin{array}{r}-0.003 \\
(0.004) \\
\end{array}$ \\
\hline $\begin{array}{l}\text { Village mean per } \\
\text { capita income }\end{array}$ & $\begin{array}{l}0.004 \\
(0.007)\end{array}$ & $\begin{array}{l}0.007 \\
(0.006)\end{array}$ & $\begin{array}{c}-0.010 \\
(0.006)^{*}\end{array}$ & $\begin{array}{l}0.006 \\
(0.006)\end{array}$ & $\begin{array}{r}-0.003 \\
(0.008)\end{array}$ & $\begin{array}{r}-0.003 \\
(0.007)\end{array}$ \\
\hline $\begin{array}{l}\text { County mean per } \\
\text { capita income }\end{array}$ & $\begin{array}{l}0.001 \\
(0.001)\end{array}$ & $\begin{array}{l}0.001 \\
(0.001)^{*}\end{array}$ & $\begin{array}{r}-0.002 \\
(0.001)\end{array}$ & $\begin{array}{l}0.002 \\
(0.001)^{* * *}\end{array}$ & $\begin{array}{l}0.005 \\
(0.001)^{* * *}\end{array}$ & $\begin{array}{l}-0.006 \\
(0.002)^{* * *}\end{array}$ \\
\hline $\begin{array}{l}\text { Share of primary } \\
\text { industry in county } \\
\text { GDP }\end{array}$ & $\begin{array}{l}0.090 \\
(0.063)\end{array}$ & $\begin{array}{r}-0.028 \\
(0.053)\end{array}$ & $\begin{array}{r}-0.062 \\
(0.060)\end{array}$ & $\begin{array}{l}0.064 \\
(0.069)\end{array}$ & $\begin{array}{r}-0.100 \\
(0.083)\end{array}$ & $\begin{array}{l}0.036 \\
(0.046)\end{array}$ \\
\hline $\begin{array}{l}\text { Village has } \\
\text { kindergarten }\end{array}$ & $\begin{array}{l}0.073 \\
(0.034)^{* *}\end{array}$ & $\begin{array}{r}-0.034 \\
(0.032)\end{array}$ & $\begin{array}{c}-0.039 \\
(0.024)^{*}\end{array}$ & $\begin{array}{l}0.020 \\
(0.031)\end{array}$ & $\begin{array}{l}0.021 \\
(0.038)\end{array}$ & $\begin{array}{r}-0.041 \\
(0.030)\end{array}$ \\
\hline
\end{tabular}




\begin{tabular}{|c|c|c|c|c|c|c|}
\hline $\begin{array}{l}\text { Village has } \\
\text { Primary school }\end{array}$ & $\begin{array}{l}0.025 \\
(0.026)\end{array}$ & $\begin{array}{c}-0.018 \\
(0.024)\end{array}$ & $\begin{array}{c}-0.007 \\
(0.018)\end{array}$ & $\begin{array}{c}-0.005 \\
(0.025)\end{array}$ & $\begin{array}{r}-0.046 \\
(0.029)\end{array}$ & $\begin{array}{l}0.050 \\
(0.023)^{* *}\end{array}$ \\
\hline $\begin{array}{l}\text { Migrants share of } \\
\text { Village labor force }\end{array}$ & $\begin{array}{r}-0.008 \\
(0.006)\end{array}$ & $\begin{array}{l}0.006 \\
(0.005)\end{array}$ & $\begin{array}{l}0.002 \\
(0.004)\end{array}$ & $\begin{array}{l}0.004 \\
(0.005)\end{array}$ & $\begin{array}{r}-0.005 \\
(0.008)\end{array}$ & $\begin{array}{l}0.001 \\
(0.006)\end{array}$ \\
\hline Inner Mongolia & $\begin{array}{l}0.309 \\
(0.037)^{* * *}\end{array}$ & $\begin{array}{l}-0.200 \\
(0.034)^{* * *}\end{array}$ & $\begin{array}{l}-0.109 \\
(0.025)^{* * *}\end{array}$ & $\begin{array}{l}0.217 \\
(0.035)^{* * *}\end{array}$ & $\begin{array}{r}-0.030 \\
(0.042)\end{array}$ & $\begin{array}{l}-0.187 \\
(0.036)^{* * *}\end{array}$ \\
\hline Human & $\begin{array}{l}0.092 \\
(0.055)^{*}\end{array}$ & $\begin{array}{c}-0.088 \\
(0.051)^{*}\end{array}$ & $\begin{array}{c}-0.005 \\
(0.037)\end{array}$ & $\begin{array}{l}0.140 \\
(0.050)^{* * *}\end{array}$ & $\begin{array}{r}-0.025 \\
(0.057)\end{array}$ & $\begin{array}{l}-0.116 \\
(0.046)^{* *}\end{array}$ \\
\hline Guangxi & $\begin{array}{l}0.079 \\
(0.050)\end{array}$ & $\begin{array}{c}-0.074 \\
(0.046)\end{array}$ & $\begin{array}{r}-0.004 \\
(0.034)\end{array}$ & $\begin{array}{l}0.219 \\
(0.044)^{* * *}\end{array}$ & $\begin{array}{c}-0.070 \\
(0.050)\end{array}$ & $\begin{array}{l}-0.149 \\
(0.038)^{* * *}\end{array}$ \\
\hline Guizhou & $\begin{array}{l}0.082 \\
(0.053)\end{array}$ & $\begin{array}{l}-0.106 \\
(0.047)^{* *}\end{array}$ & $\begin{array}{l}0.024 \\
(0.040)\end{array}$ & $\begin{array}{l}0.096 \\
(0.044)^{* *}\end{array}$ & $\begin{array}{l}0.042 \\
(0.053)\end{array}$ & $\begin{array}{l}-0.137 \\
(0.042)^{* * *}\end{array}$ \\
\hline Qinghai & $\begin{array}{l}0.063 \\
(0.047)\end{array}$ & $\begin{array}{r}-0.050 \\
(0.044)\end{array}$ & $\begin{array}{r}-0.013 \\
(0.031)\end{array}$ & $\begin{array}{c}-0.078 \\
(0.031)^{* *}\end{array}$ & $\begin{array}{l}0.080 \\
(0.047)^{*}\end{array}$ & $\begin{array}{c}-0.003 \\
(0.043)\end{array}$ \\
\hline Xinjiang & $\begin{array}{l}0.274 \\
(0.054)^{* * *}\end{array}$ & $\begin{array}{l}-0.217 \\
(0.041) * * *\end{array}$ & $\begin{array}{c}-0.057 \\
(0.043)\end{array}$ & $\begin{array}{l}0.234 \\
(0.063)^{* * *}\end{array}$ & $\begin{array}{l}0.009 \\
(0.067)\end{array}$ & $\begin{array}{l}-0.243 \\
(0.048)^{* * *}\end{array}$ \\
\hline $\begin{array}{l}\text { Chi2 } \\
\text { P value }\end{array}$ & $\begin{array}{r}402.53 \\
0.00\end{array}$ & $\begin{array}{r}402.53 \\
0.00\end{array}$ & $\begin{array}{r}402.53 \\
0.00\end{array}$ & $\begin{array}{r}613.64 \\
0.00\end{array}$ & $\begin{array}{r}613.64 \\
0.00\end{array}$ & $\begin{array}{r}613.64 \\
0.00\end{array}$ \\
\hline No. observations & 1,479 & 1,479 & 1,479 & 1,514 & 1,514 & 1,514 \\
\hline
\end{tabular}

${ }^{*} p<0.1$; ** $p<0.05$; *** $p<0.01$

Source: China Household Ethnicity Survey 2012. 


\section{Appendices}

Table A1 Summary Statistics of explanatory variables (not included in Tables 1-3)

\begin{tabular}{|c|c|c|c|c|c|c|}
\hline & \multicolumn{2}{|c|}{ Muslim } & \multicolumn{2}{|c|}{$\begin{array}{l}\text { Non-Muslim } \\
\text { Minority }\end{array}$} & \multicolumn{2}{|c|}{ Han } \\
\hline & Women & Men & Women & Men & Women & Men \\
\hline \multicolumn{7}{|l|}{ Age Group Distribution: } \\
\hline Ages 25-29 & 0.211 & 0.224 & 0.198 & 0.164 & 0.172 & 0.124 \\
\hline Ages 30-34 & 0.196 & 0.202 & 0.187 & 0.205 & 0.191 & 0.178 \\
\hline Ages 35-39 & 0.231 & 0.259 & 0.283 & 0.294 & 0.314 & 0.339 \\
\hline Ages 40-45 & 0.120 & 0.177 & 0.198 & 0.257 & 0.227 & 0.302 \\
\hline $\begin{array}{l}\text { Household's Asset income } \\
\text { (1000 yuan) }\end{array}$ & $\begin{array}{l}0.053 \\
(0.299)\end{array}$ & $\begin{array}{l}0.050 \\
(0.294)\end{array}$ & $\begin{array}{l}0.063 \\
(0.389)\end{array}$ & $\begin{array}{l}0.064 \\
(0.390)\end{array}$ & $\begin{array}{l}0.169 \\
(1.189)\end{array}$ & $\begin{array}{l}0.159 \\
(1.158)\end{array}$ \\
\hline $\begin{array}{l}\text { Distance from village to } \\
\text { nearest bus stop }\end{array}$ & $\begin{array}{l}6.390 \\
(9.757)\end{array}$ & $\begin{array}{l}6.170 \\
(9.426)\end{array}$ & $\begin{array}{l}13.167 \\
(18.615)\end{array}$ & $\begin{array}{l}13.329 \\
(18.638)\end{array}$ & $\begin{array}{l}8.606 \\
(15.013)\end{array}$ & $\begin{array}{l}8.635 \\
(15.342)\end{array}$ \\
\hline Village mean per capita land & $\begin{array}{l}3.553 \\
(5.274) \\
\end{array}$ & $\begin{array}{l}3.488 \\
(5.096)\end{array}$ & $\begin{array}{l}3.202 \\
(18.291)\end{array}$ & $\begin{array}{l}3.377 \\
(19.516)\end{array}$ & $\begin{array}{l}3.957 \\
(4.292)\end{array}$ & $\begin{array}{l}3.958 \\
(4.270) \\
\end{array}$ \\
\hline $\begin{array}{l}\text { Village mean per capita } \\
\text { income ( } 1000 \text { yuan) }\end{array}$ & $\begin{array}{l}4.541 \\
(1.362)\end{array}$ & $\begin{array}{l}4.528 \\
(1.354)\end{array}$ & $\begin{array}{l}3.737 \\
(1.692)\end{array}$ & $\begin{array}{l}3.744 \\
(1.702)\end{array}$ & $\begin{array}{l}5.127 \\
(2.923)\end{array}$ & $\begin{array}{l}5.091 \\
(2.900)\end{array}$ \\
\hline $\begin{array}{l}\text { County per capita GDP } \\
\text { (1000 yuan) }\end{array}$ & $\begin{array}{l}14.332 \\
(9.113) \\
\end{array}$ & $\begin{array}{l}14.309 \\
(9.080)\end{array}$ & $\begin{array}{l}16.738 \\
(20.423)\end{array}$ & $\begin{array}{l}16.373 \\
(19.772)\end{array}$ & $\begin{array}{l}25.334 \\
(25.298) \\
\end{array}$ & $\begin{array}{l}25.030 \\
(24.886)\end{array}$ \\
\hline $\begin{array}{l}\text { Share of primary industry in } \\
\text { county GDP }\end{array}$ & $\begin{array}{l}0.453 \\
(0.620) \\
\end{array}$ & $\begin{array}{l}0.453 \\
(0.623)\end{array}$ & $\begin{array}{l}0.236 \\
(0.076) \\
\end{array}$ & $\begin{array}{l}0.235 \\
(0.076)\end{array}$ & $\begin{array}{l}0.251 \\
(0.208)\end{array}$ & $\begin{array}{l}0.250 \\
(0.206)\end{array}$ \\
\hline $\begin{array}{l}\text { Share of villages with } \\
\text { kindergarten }\end{array}$ & $\begin{array}{l}0.069 \\
(0.254) \\
\end{array}$ & $\begin{array}{l}0.070 \\
(0.255)\end{array}$ & $\begin{array}{l}0.165 \\
(0.371) \\
\end{array}$ & $\begin{array}{l}0.168 \\
(0.374)\end{array}$ & $\begin{array}{l}0.136 \\
(0.343)\end{array}$ & $\begin{array}{l}0.139 \\
(0.346)\end{array}$ \\
\hline $\begin{array}{l}\text { Share of villages with primary } \\
\text { school }\end{array}$ & $\begin{array}{l}0.768 \\
(0.422) \\
\end{array}$ & $\begin{array}{l}0.767 \\
(0.423)\end{array}$ & $\begin{array}{l}0.680 \\
(0.466) \\
\end{array}$ & $\begin{array}{l}0.685 \\
(0.465) \\
\end{array}$ & $\begin{array}{l}0.591 \\
(0.492) \\
\end{array}$ & $\begin{array}{l}0.590 \\
(0.492)\end{array}$ \\
\hline $\begin{array}{l}\text { Migrants share of village } \\
\text { labor force }\end{array}$ & $\begin{array}{l}0.394 \\
(0.255) \\
\end{array}$ & $\begin{array}{l}0.399 \\
(0.254)\end{array}$ & $\begin{array}{l}0.415 \\
(0.216) \\
\end{array}$ & $\begin{array}{l}0.413 \\
(0.215) \\
\end{array}$ & $\begin{array}{l}0.400 \\
(0.214)\end{array}$ & $\begin{array}{l}0.403 \\
(0.216)\end{array}$ \\
\hline \multicolumn{7}{|l|}{$\begin{array}{l}\text { Distribution of Provincial } \\
\text { Locations: }\end{array}$} \\
\hline Inner Mongolia & ---- & ---- & 0.074 & 0.069 & 0.227 & 0.229 \\
\hline Hunan & ---- & ---- & 0.214 & 0.221 & 0.100 & 0.092 \\
\hline Guangxi & ---- & ---- & 0.230 & 0.230 & 0.122 & 0.124 \\
\hline Guizhou & ---- & ---- & 0.343 & 0.349 & 0.097 & 0.097 \\
\hline Qinghai & 0.226 & 0.249 & 0.131 & 0.124 & 0.160 & 0.166 \\
\hline Ningxia & 0.333 & 0.326 & 0.006 & 0.005 & 0.180 & 0.180 \\
\hline Xinjiang & 0.441 & 0.425 & 0.002 & 0.002 & 0.115 & 0.112 \\
\hline Number of Observations & 897 & 916 & 1,798 & 1,777 & 1,477 & 1,514 \\
\hline
\end{tabular}

Source: China Household Ethnicity Survey 2012. 